\title{
Phosphorylation-Related Crosstalk Between Distant Regions of the Core Region of the Coat Protein Contributes to Virion Assembly of Plum Pox Virus
}

\author{
Marta Hervás, ${ }^{1}$ Rosana Navajas, ${ }^{2}$ Mónica Chagoyen, ${ }^{3}$ Juan Antonio García, ${ }^{1+}$ and \\ Sandra Martínez-Turiño ${ }^{1,+}$ \\ ${ }^{1}$ Department of Plant Molecular Genetics, Centro Nacional de Biotecnología (CNB-CSIC), Campus Universidad Autónoma de \\ Madrid, Madrid 28049, Spain \\ ${ }^{2}$ Proteomics Unit, CNB-CSIC, ProteoRed ISCIII, Madrid 28049, Spain \\ ${ }^{3}$ Computational Systems Biology Group, CNB-CSIC, Madrid 28049, Spain
}

Accepted 19 December 2019.

Eukaryotic proteins are often targets of posttranslational modifications (PTMs). Capsid protein (CP) of plum pox virus (PPV), a member of genus Potyvirus, has been reported to be prone to phosphorylation in four serines at the N-terminal region. CP phosphorylation has been proposed to influence PPV infection by regulating $\mathrm{CP}$ accumulation in coordination with a second PTM, $O$-GIcNAcylation. In this study, a further proteomic characterization of PPV CP phosphorylation revealed additional phospho-targets, thus evidencing even greater complexity of the network of PTMs affecting this protein. In particular, two new phosphorylation targets, T254 and T313, at protein distal core, appear to be highly relevant for infection. Although abolishing phosphorylation at these positions does not have a severe effect on infectivity or viral accumulation, phospho-mimicking at either of these targets disrupts cell-to-cell movement. Strand-specific reverse transcription-quantitative PCR analysis and fractionation by centrifugation in a continuous sucrose gradient enabled us to conclude that such a deleterious effect is not related to failures in replication but is a consequence of inaccurate virion assembly. The analysis of spontaneous compensatory mutations at the $\mathbf{C P}$ core identified in a multiple phospho-mimicking mutant disclosed a functional dialogue between distant phospho-targets, which was further supported by an in silico PPV virion model, built on the watermelon mosaic virus atomic structure. Therefore, whereas joint and opposite action of $\boldsymbol{O}$-GlcNAcylation and phosphorylation at the $\mathrm{N}$-terminal disordered protrusion of $\mathrm{CP}$ appears to regulate protein stability, we propose that phosphorylations at the core region control assembly and disassembly of viral particles.

${ }^{\dagger}$ Corresponding authors: S. Martínez Turiño; sandra.martinez@cnb.csic.es and J. A. García; jagarcia@cnb.csic.es

Funding: This work was supported by the Spanish Ministerio de Ciencia e Innovación y Universidades (MICINN) grant BIO2016-80572-R (AEIFEDER). M. Hervás was supported by the Programa de Formación de Doctores of MICINN grant BES-2014-067645.

*The $\boldsymbol{e}$-Xtra logo stands for "electronic extra" and indicates that supplementary figures and tables are published online.

The author(s) declare no conflict of interest.

(c) 2020 The American Phytopathological Society
Keywords: coat protein, PTM, phosphorylation, sharka, plum pox virus, Potyvirus, virion assembly, virion stability

Posttranslational modifications (PTMs) largely expand the proteome width and facilitate prompt dynamic regulations and signaling processes (Gelens and Saurin 2018; Xu and Zhang 2015). This can be especially important in RNA viruses, whose gene-encoding capacity is rather limited (Cheng et al. 2017; Jakubiec and Jupin 2007).

Phosphorylation is probably the PTM with greater functional relevance. This reversible PTM is conserved in all living organisms and has been extensively studied in bacteria, animals, and plants (Gelens and Saurin 2018; Kobir et al. 2011; Mundy and Schneitz 2002; Pawson and Scott 2005). Scientific literature gathers a wide variety of reports on proteins of plant and animal viruses with DNA or RNA genomes, which are modified by phosphorylation. Such proteins may be involved in any of the processes of viral infection, including transcription and replication of viral DNA or RNA, RNA translation, virus movement, or virus particle assembly (Hoover and Kao 2016; Jakubiec and Jupin 2007; Keating and Striker 2012; Keck et al. 2015).

In the particular case of plant single-stranded (ss)RNA viruses, examples of nonstructural proteins found to be phosphorylated include the replication proteins $2 \mathrm{a}$ of the cucumovirus cucumber mosaic virus (CMV) (Kim et al. 2002), p33 of the tombusvirus cucumber necrosis virus (Shapka et al. 2005), and $66 \mathrm{~K}$ of the tymovirus turnip yellow mosaic virus (TYMV) (Jakubiec et al. 2006), the movement proteins $30 \mathrm{~K}$ of the tobamovirus tobacco mosaic virus (Citovsky et al. 1993), 32K of the alfamovirus alfalfa mosaic virus (Kim et al. 2014), TGBp1 of the potexvirus potato virus X (PVX) (Módena et al. 2008), TGB1 of the hordeivirus barley stripe mosaic virus (BSMV) (Hu et al. 2015), TGBp3 of the pomovirus pop moptop virus (Samuilova et al. 2013), 17K of the polerovirus potato leafroll virus (Sokolova et al. 1997), as well as the RNA silencing suppressors $2 \mathrm{~b}$ of the cucumovirus CMV (Nemes et al. 2017) and $\gamma$ b of BSMV (Zhang et al. 2018).

Protein phosphorylation appears to be especially relevant for specific functions of structural proteins of plant ssRNA viruses. Thus, phosphorylation of capsid proteins (CPs) of two potexviruses, PVX (Atabekov et al. 2001) and bamboo mosaic virus (BaMV) (Hung et al. 2014), has been shown to, respectively, promote translational activation of the encapsidated genomic 
RNA and regulate cell-to-cell movement through modulating its RNA binding. Similarly, the phosphorylation degree modulates interaction between $\mathrm{CP}$ of the bromovirus brome mosaic virus (BMV) and encapsidated RNA and regulates the timing of viral infection by determining specific disassembly rates for the three distinct virus particles (Hoover et al. 2016). In the case of the necrovirus beet black scorch virus (BBSV), accurate $\mathrm{CP}$ phosphorylation is necessary for packaging of the genomic RNA into stable virions and, consequently, for long-distance viral movement (Zhao et al. 2015). More recently, phosphorylation of the $\mathrm{CP}$ of $\mathrm{CMV}$ has been connected with its role in symptom recovery when regulating the self-attenuation mechanism and downregulating viral silencing suppressor $2 \mathrm{~b}$ protein (Nemes et al. 2019).

The Potyvirus genus constitutes the largest group of plant RNA viruses. Potyviruses have a ssRNA genome of approximately $10 \mathrm{~kb}$ that contains an open reading frame (ORF) spanning its complete length. This ORF encodes a long polyprotein that includes the $\mathrm{CP}$ at its $\mathrm{C}$ terminus and is proteolytically processed by virus-encoded proteinases (Ivanov et al. 2014; Revers and García 2015; Valli et al. 2020). Fusion of the main ORF with an internal small one by viral RNA polymerase slippage yields an additional transframe viral product (Chung et al. 2008; Olspert et al. 2015; Rodamilans et al. 2015). Probably, the best-studied case of CP phosphorylation in a plant ssRNA virus is that of the $\mathrm{CP}$ of the potyvirus potato virus A (PVA). PVA CP is phosphorylated when it is not assembled in virions (Ivanov et al. 2001), mainly by protein kinase CK2 in a threonine residue located at the distal core of the protein (Ivanov et al. 2001). Phosphorylation of the PVA CP inhibits its RNA-binding capacity (Ivanov et al. 2001), and results obtained after testing some phospho-deficient and phospho-mimicking $\mathrm{CP}$ mutants suggested that a dynamic balance between CP phosphorylation and dephosphorylation is crucial for PVA replication (Ivanov et al. 2003; Lõhmus et al. 2017). From that, a model has been proposed involving CP phosphorylation in translation-replication switching, i.e., nonphosphorylated CP binds viral RNA near its $3^{\prime}$ end and blocks translation and, next, subsequent phosphorylation of CP assists the CPIP/HSP70 chaperone system (Hafrén et al. 2010) in detaching CP to open viral RNA for the replication reactions (Lõhmus et al. 2017). However, the positive effect on PVA CP stability of a mutation emulating phosphorylation (Lõhmus et al. 2017) suggests this modification could play an additional role in the dynamics of $\mathrm{CP}$ accumulation not directly related to its RNA binding affinity.

A second potyviral $\mathrm{CP}$ that has been found to be phosphorylated is that of plum pox virus (PPV) (Chen et al. 2005; FernándezFernández et al. 2002; Martínez-Turiño et al. 2018). However, PPV CP phosphorylation appears to notably differ from that of PVA CP. i) In contrast with PVA CP phosphorylation, which does not affect protein assembled in virions (Ivanov et al. 2001), PPV CP phosphorylation has been detected in purified viral particles; ii) PPV CP phosphorylation affects four specific serines at the $\mathrm{N}$-terminal third of the protein, very distant from the site equivalent to the main phosphorylation target of PVA $\mathrm{CP}$; and iii) similarly to what happens in many other animal and plant proteins (van der Laarse et al. 2018; Xu et al. 2017), PPV CP phosphorylation can coexist with a second PTM, $O$ GlcNAcylation (Kim et al. 2011; Pérez et al. 2013), and a coordinated action of both in regulating $\mathrm{CP}$ accumulation has been proposed (Martínez-Turiño et al. 2018).

In this paper, we uncover the complexity of PPV CP phosphorylation, which is greater than that initially described, and unravel functional connections between phosphorylations occurring at distant regions of the protein, and describe how they contribute to virion assembly and virus movement.

\section{RESULTS}

Phosphorylation affects PPV CP in multiple targets.

In a previous report, we described how the $\mathrm{CP}$ of PPV virions is prone to phosphorylation in vivo at four serines, at the $\mathrm{N}$ terminus (pS25, pS81 and pS101), and at the beginning of the core protein region (pS118) (Martínez-Turiño et al. 2018). In the course of that study and in order to determine the influence of the CP phosphorylation state on PPV infection, we obtained a multiple PPV mutant in which S25, S81, S101, and S118 were replaced by alanine residues (the 4 SA mutant) to prevent any $\mathrm{CP}$ phosphorylation. However, when 4SA virions were subjected to a 2D-PAGE (two-dimensional polyacrylamide gel electrophoresis) separation, the second dimension still showed clearly discernible spot "trains" along the horizontal axis, which could correspond to differentially phosphorylated protein species (Supplementary Fig. S1).

The possible presence of phospho-targets in 4SA virions was assessed by tandem mass spectrometry (MS/MS) following a bottom-up phosphoproteomics strategy. Virions were subjected to digestion with Lys-C and trypsin proteases, and resulting peptides were phospho-enriched prior to their analysis by a nano liquid chromatography (LC)-MS/MS high-resolution Triple time-offlight (TOF) system in a data-dependent acquisition mode, where a subset of the most abundant precursor peptide ions was individually selected and fragmented to generate corresponding mass spectra, following collision-induced dissociation MS/MS fragmentation technique. One or both of the Mascot and Peaks search engines allowed peptide identification by matching experimental data with theoretical MS/MS spectra derived from a homebuilt database that includes PPV CP sequence of nonmutated virus and its mutated versions. In addition, manual validation of identified phosphopeptides was also performed. This phosphoproteomics strategy unequivocally mapped four phosphorylationprone threonine residues at positions $71,106,254$, and 313 in the CP of 4SA mutant (Fig. 1A and C; Supplementary Table S1). However, peptides phosphorylated at these threonine residues were more rarely detected than those modified at the serine targets previously identified (S25, S81, S101, and S118).

From this finding a more comprehensive analysis of nonmutated PPV virions was carried out. While phospho-threonines at residues $71,106,254$, and 313 were reliably identified in 4SA virions, only two of these four phospho-targets (T254 and T313) could be distinguished in wild-type (WT) virions. However, they were detected with less confident Mascot score consideration and after comparing low-quality MS/MS fragmentation spectra obtained from WT virions with higher quality ones corresponding to $4 \mathrm{SA}$ virions (Fig. 1B).

\section{Phospho-mimicking in the phosphorylatable residues T254 and T313 of CP is deleterious for PPV infection.}

Detection of phosphorylation at T254 looks especially interesting because a potentially compensatory mutation at this position (T254K) had been previously detected in the progeny of the multiple phospho-mimicking mutant 4SD (MartínezTuriño et al. 2018). Phosphorylation at T313 also interested us because it is placed at the end of the core region of the protein, where phosphorylation of the $\mathrm{CP}$ of the potyvirus PVA takes place (Ivanov et al. 2001, 2003).

To assess the possible relevance of these newly detected phosphorylations, phosphorylatable threonines 254 and 313 were replaced by alanine $\left(\mathrm{CP}^{\mathrm{T} 254 \mathrm{~A}}\right.$ and $\left.\mathrm{CP}^{\mathrm{T} 313 \mathrm{~A}}\right)$, to prevent phosphorylation, or by aspartic acid $\left(\mathrm{CP}^{\mathrm{T} 254 \mathrm{D}}\right.$ and $\left.\mathrm{CP}^{\mathrm{T} 313 \mathrm{D}}\right)$, to emulate a constitutive phosphorylated state. A silent mutation in the codon $\mathrm{T} 254\left(\mathrm{CP}^{\mathrm{T} 254 \mathrm{~T}^{*}}\right)$ and a mutation replacing $\mathrm{T} 313$ by asparagine $\left(\mathrm{CP}^{\mathrm{T} 313 \mathrm{~N}}\right)$, a neutral amino acid with a side chain as bulky as that of the negatively charged aspartic, were included as 
controls. All these changes were engineered into the full-length cDNA clone pICPPV-NK-1GFP, which encodes a copy of the green fluorescent protein (GFP)-expressing recombinant PPV genome (Supplementary Fig. S2).
Nicotiana benthamiana plants were inoculated by hand rubbing with cDNA from the different viral clones, and the course of viral infection was tracked by visual inspection of symptoms and monitoring of GFP fluorescence. In a first
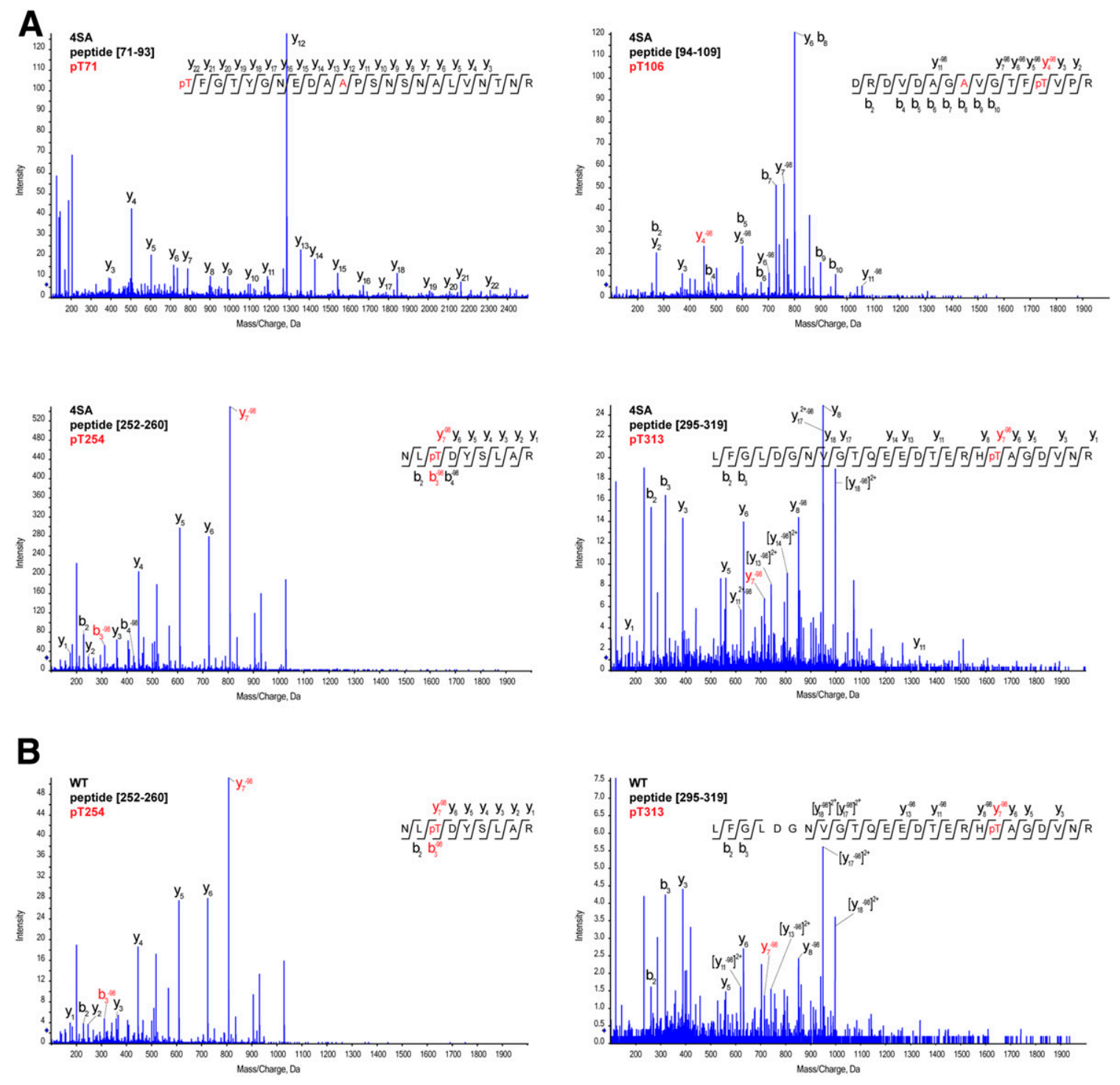

\section{N-t protrusion}

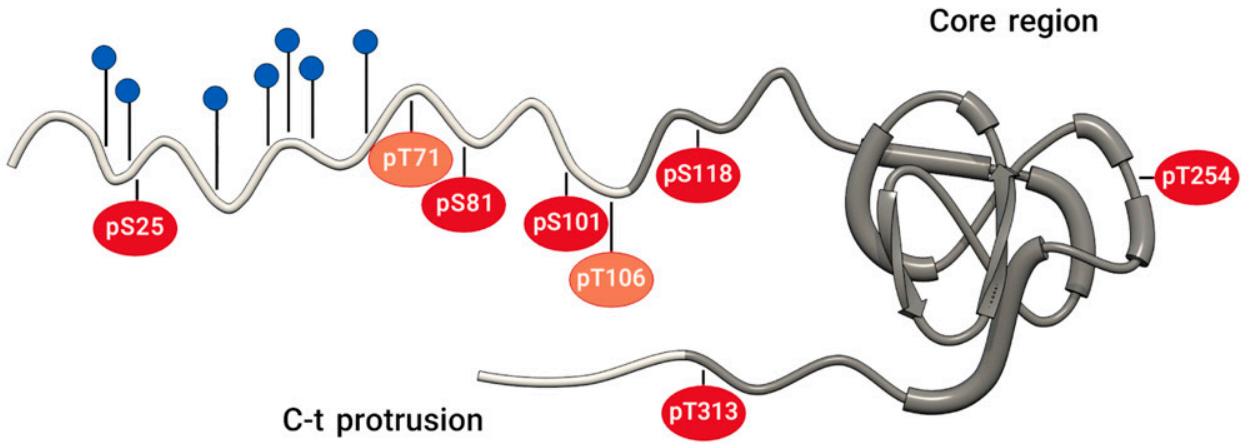

Fig. 1. Plum pox virus (PPV) capsid protein (CP) phosphorylations affecting threonine residues (pT71, pT106, pT254, and pT313). Collision-induced dissociation-tandem mass spectrometry spectra corresponding to A, phosphorylated PPV CP peptides mapped in a phospho-abolishing multiple mutant (4SA) and $\mathbf{B}$, in the nonmutated virus (wild type [WT]). Some of the changes engineered in the 4SA mutant, affecting serine phospho-targets (S81A and S101A) and newly mapped phospho-threonines in 4SA and WT CPs are highlighted in red. C, Scheme of PPV CP and its posttranslational modifications showing the distribution of phosphorylations detected in both 4SA mutant and WT virus (red ellipses) or just in 4SA virus (orange ellipses). $O$-GlcNAcylated amino acids previously mapped in WT virions are also marked (blue spheres). N- and C-terminal protrusions (light gray) and the alpha helix-rich core region (dark gray) were defined based on the structure described for the CP of the potyvirus watermelon mosaic virus (Zamora et al. 2017). 
experiment, plants were challenged with $\mathrm{CP}^{\mathrm{T} 254 \mathrm{~A}}, \mathrm{CP}^{\mathrm{T} 254 \mathrm{D}}$, and $\mathrm{CP}^{\mathrm{T} 254 \mathrm{~T}^{*}}$ mutants as well as with the nonmutated virus. Symptoms and GFP fluorescence compatible with PPV infection were detected at 8 days postinfection (dpi) in most plants inoculated with the WT virus and in a few plants in the case of mutants $\mathrm{CP}^{\mathrm{T} 254 \mathrm{~A}}$ and $\mathrm{CP}^{\mathrm{T} 254 \mathrm{~T}^{*}}$. However, at a later time, the number of plants with signs of infection and the intensity of symptoms and GFP fluorescence tended to be similar for both mutants compared with nonmutated virus. At 16 dpi, all plants inoculated with $\mathrm{CP}^{\mathrm{T} 254 \mathrm{~A}}$ and $\mathrm{CP}^{\mathrm{T} 254 \mathrm{~T}^{*}}$ were infected (6 of 6); yet, none of those inoculated with the $\mathrm{CP}^{\mathrm{T} 254 \mathrm{D}}$ mutant appeared to be infected (0 of 6) (Supplementary Table S3).

At $28 \mathrm{dpi}$, upper noninoculated leaves of plants infected with the mutant preventing phosphorylation in residue 254 $\left(\mathrm{CP}^{\mathrm{T} 254 \mathrm{~A}}\right)$ or with the control virus bearing the silent mutation $\left(\mathrm{CP}^{\mathrm{T} 254 \mathrm{~T}^{*}}\right)$ showed abundant GFP expression, and an immunoblot assay revealed similar levels of viral $\mathrm{CP}$ accumulation compared with the WT virus. In contrast, neither GFP fluorescence nor viral $\mathrm{CP}$ accumulation was detected in the $\mathrm{CP}^{\mathrm{T} 254 \mathrm{D}}$-inoculated plants (Fig. 2A and C; Supplementary Table S3). Immunocapture reverse transcription PCR (IC-RTPCR) amplification from upper noninoculated leaves and sequencing of a cDNA fragment encompassing the $\mathrm{CP}$ coding region revealed the stability of T254A and T254T* mutants and confirmed lack of infectivity of the phospho-mimicking mutant $\mathrm{CP}^{\mathrm{T} 254 \mathrm{D}}$.

In a second experiment, plants were inoculated with cDNA from the $\mathrm{CP}^{\mathrm{T} 313 \mathrm{~A}}, \mathrm{CP}^{\mathrm{T} 313 \mathrm{D}}, \mathrm{CP}^{\mathrm{T} 313 \mathrm{~N}}$, and WT clones. Symptom and GFP monitoring detected systemic infection as early as 7 dpi in most of the plants inoculated with the WT virus. In contrast, signs of infection by mutants $\mathrm{CP}^{\mathrm{T} 313 \mathrm{~A}}$ and $\mathrm{CP}^{\mathrm{T} 313 \mathrm{~N}}$ could be detected only in a low proportion of the inoculated plants and only from 18 dpi onward. None of the plants inoculated with the $\mathrm{CP}^{\mathrm{T} 313 \mathrm{D}}$ mutant appeared to be infected. GFP fluorescence monitoring and anti-CP immunoblot analysis showed reduced viral accumulation in $N$. benthamiana plants infected with the virus containing a mutation preventing phosphorylation $\left(\mathrm{CP}^{\mathrm{T} 313 \mathrm{~A}}\right)$, as compared with the $\mathrm{WT}$ virus or the control mutant $\left(\mathrm{CP}^{\mathrm{T} 313 \mathrm{~N}}\right)$. Neither GFP fluorescence nor $\mathrm{CP}$ accumulation, as assessed by immunoblot analysis, was detected in the $\mathrm{CP}^{\mathrm{T} 313 \mathrm{D}}$-inoculated plants (Fig. 2B and D; Supplementary Table S3). IC-RT-PCR amplification from upper noninoculated leaves and sequencing of a cDNA fragment of the $\mathrm{CP}$ coding region showed genetic stability of $\mathrm{CP}^{\mathrm{T} 313 \mathrm{~A}}$ and $\mathrm{CP}^{\mathrm{T} 313 \mathrm{~N}}$ mutants and confirmed absence of virus in the $\mathrm{CP}^{\mathrm{T} 313 \mathrm{D}}$-inoculated plants.

These results show that, whereas lack of phosphorylation of PPV CP at T254 or T313 has only limited effects (more pronounced in the case of T313) on PPV infection, constitutively mimicking phosphorylation at any of these residues completely precludes viral infection.

\section{Phospho-mimicking in specific residues at distal core of PPV CP negatively affects viral cell-to-cell movement.}

To increase chances of infection by the phospho-mimicking mutants at residues 254 and 313 and to facilitate identification of the step of virus infection disturbed by the T254D and T313D mutations, these amino acid changes were engineered into the binary vector $\mathrm{pLX}-\mathrm{PPV}$, suitable for inoculation by leaf infiltration with Agrobacterium tumefaciens. $N$. benthamiana leaves were agroinfiltrated with bacterial cultures expressing constructs pLX-PPV-CP ${ }^{\mathrm{T} 254 \mathrm{D}}\left(\mathrm{aCP}^{\mathrm{T} 254 \mathrm{D}}\right)$ or pLX-PPV$\mathrm{CP}^{\mathrm{T} 313 \mathrm{D}}\left(\mathrm{aCP}^{\mathrm{T} 313 \mathrm{D}}\right)$ (Supplementary Fig. S2). The WT pLX$\mathrm{PPV}(\mathrm{aWT})$ and the construct pBIN-PPV-CI ${ }^{\mathrm{DD} 3,4 \mathrm{AA}}\left(\mathrm{aCI}^{\mathrm{DD3}, 4 \mathrm{AA}}\right)$,

\section{A}

WT
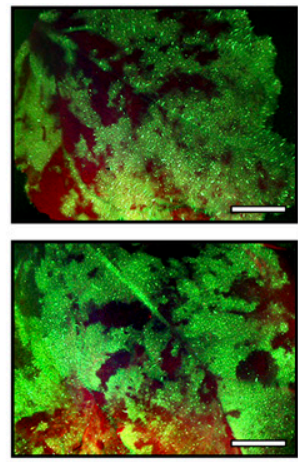

CPT254A

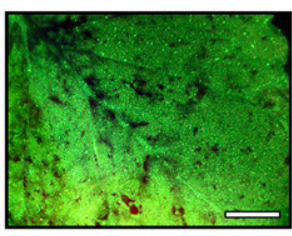

CPT254D

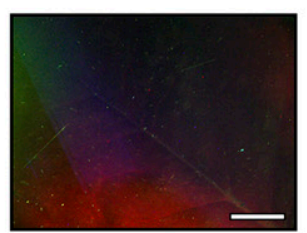

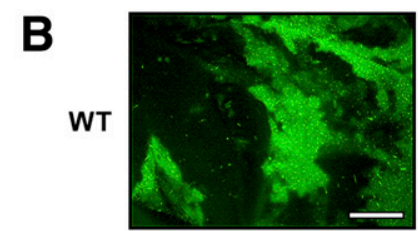

CPT313N
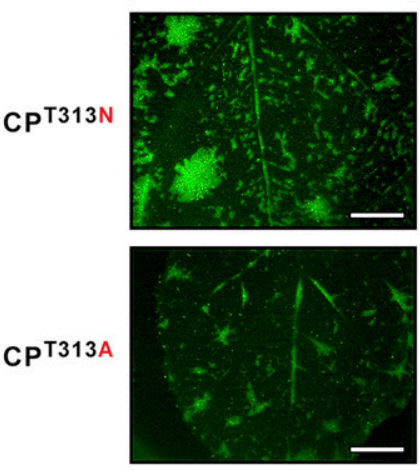

CPT313D

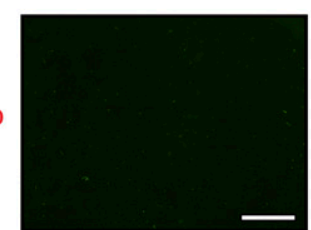

C

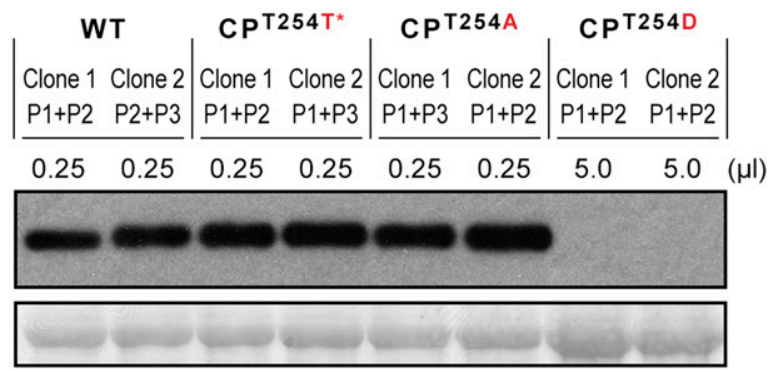

D

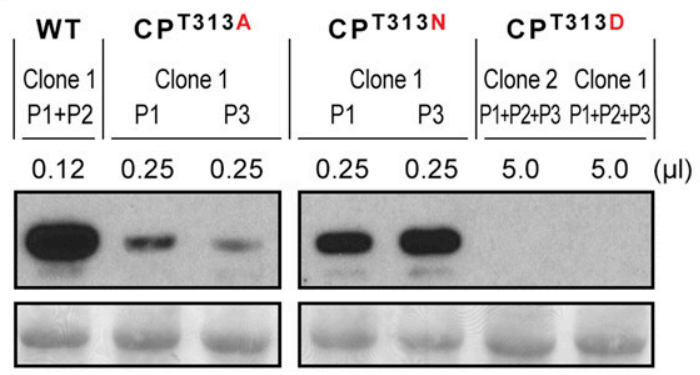

Fig. 2. Infection of Nicotiana benthamiana plants by wild-type plum pox virus (PPV) (WT) and mutants bearing changes at threonine 254 or 313 , preventing $\left(\mathrm{CP}^{\mathrm{T} 254 \mathrm{~A}}, \mathrm{CP}^{\mathrm{T} 313 \mathrm{~A}}\right)$ or mimicking $\left(\mathrm{CP}^{\mathrm{T} 254 \mathrm{D}}, \mathrm{CP}^{\mathrm{T} 313 \mathrm{D}}\right)$ phosphorylation of capsid protein $(\mathrm{CP})$ at these positions. A and $\mathbf{B}$, Images of upper uninoculated leaves of plants inoculated with the indicated viruses taken under an epifluorescence microscope. C and D, PPV CP-specific immunoblot analysis of extracts from individual or pooled plants $(\mathrm{P} 1, \mathrm{P} 2$, and $\mathrm{P} 3)$. Third mutants $\left(\mathrm{CP}^{\mathrm{T} 254 \mathrm{~T}^{*}}\right.$ or $\left.\mathrm{CP}^{\mathrm{T} 313 \mathrm{~N}}\right)$ were also included as mutational controls in each assay. Plants were inoculated by hand rubbing with viral cDNA, and upper uninoculated leaves were collected at 28 (mutants affected in residue 254 ) and 21 (mutants affected in residue 313 ) days postinoculation. Scale bars in A and B $=5 \mathrm{~mm}$. Inoculated viruses, viral cDNA clones, analyzed plants, and loaded extract volumes are indicated. Blots stained with Ponceau red showing the ribulose-1,5-bisphopshate carboxylase/oxygenase protein are included as loading controls. Assay was carried out twice, rendering similar results in both cases. 
containing the cDNA of a movement-deficient PPV mutant, were used as controls. All infiltration mixtures also included cells harboring plasmids pGWB-RFP and pMDC-P1b (P1b), encoding the red fluorescent protein (RFP) and the RNA silencing suppressor $\mathrm{P} 1 \mathrm{~b}$ of cucumber vein yellowing virus (CVYV), respectively. Monitoring of GFP and RFP fluorescence showed that the GFPtagged CP mutants, similarly to the CI mutant known to be unable to move cell-to-cell, remained confined in the patch expressing the RFP, contrary to the WT virus, which clearly exceeded the red marker limits (Fig. 3).

In order to discriminate whether the GFP detected in the $\mathrm{aCP}^{\mathrm{T} 254 \mathrm{D}}$ - and $\mathrm{aCP}^{\mathrm{T} 313 \mathrm{D}}$-agroinfiltrated patches was produced by replicating viruses or was a result of transient expression of nonreplicating viral cDNAs, an experiment assessing viral RNA replication was conducted. $N$. benthamiana leaves were massively infiltrated with mixtures of Agrobacterium cultures expressing cDNAs of the PPV mutants to be tested, $\mathrm{aCP}^{\mathrm{T} 254 \mathrm{D}}$ or aCP ${ }^{\mathrm{T} 313 \mathrm{D}}$. aWT and pBIN-PPV-CI ${ }^{\mathrm{KS} 91,92 \mathrm{AA}}\left(\mathrm{aCI}^{\mathrm{KS} 91,92 \mathrm{AA}}\right)$, containing the cDNA of a PPV mutant unable to replicate, were used as positive and negative replication controls, respectively. Infiltration mixtures always included bacteria expressing the CVYV RNA silencing suppressor P1b. The ability to carry out viral genome replication in the agroinfiltrated leaves was analyzed at 5 dpi, by quantification of virus-derived negative RNA, by a strand-specific reverse transcription-quantitative PCR (RTqPCR). Values from $\mathrm{aCP}^{\mathrm{T} 254 \mathrm{D}}$ and $\mathrm{aCP} \mathrm{P}^{\mathrm{T} 313 \mathrm{D}}$ samples were slightly lower than those of the WT virus but significantly higher than the background value of the nonreplicating virus sample

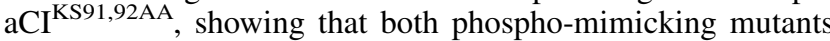
were able to replicate (Fig. 4).

Around two weeks after collecting the infiltrated leaves used for RT-qPCR analysis, upper leaves of some of the $N$. benthamiana plants inoculated with $\mathrm{aCP}^{\mathrm{T} 254 \mathrm{D}}$ or aCP ${ }^{\mathrm{T} 313 \mathrm{D}}$ mutants developed mild symptoms compatible with PPV infection (not shown). IC-RT-PCR analysis of these leaves confirmed that at least six plants inoculated with $\mathrm{aCP}^{\mathrm{T} 254 \mathrm{D}}$ and three inoculated with $\mathrm{aCP} \mathrm{P}^{\mathrm{T} 313 \mathrm{D}}$ were systemically infected, and sequencing of the amplified cDNA indicated that viral progenies had evolved by suffering spontaneous mutations. Out of a total of six plants infected with the $\mathrm{CP}^{\mathrm{T} 254 \mathrm{D}}$ mutant, all sustained changes at $\mathrm{D} 254$, to asparagine (D254N) in five of six plants and to isoleucine (D254I) in one. In the case of those plants inoculated with the $\mathrm{aCP}^{\mathrm{T} 313 \mathrm{D}}$ clone, the initial mutation T313D was maintained in the three plants that were shown to be infected but all of them incorporated a second-site mutation, different in each plant: N301K, E235G, and T254R. Of note, although they affected very distant residues, the three second-site mutations coincided in causing a gain of net charge, and one of them affected the phospho-target T254.

All these findings together support the assumption that emulating a constitutive phosphorylation in the distal core of PPV CP does not noticeably affect viral replication but drastically disturbs the short-distance movement capacity of the virus.

\section{No viral movement}

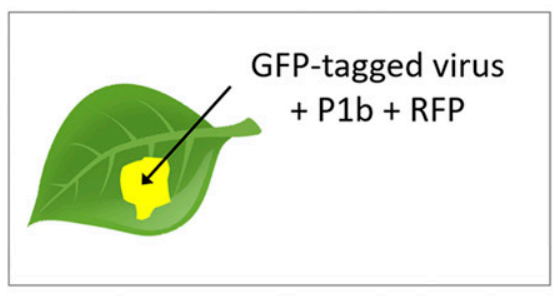

Viral movement

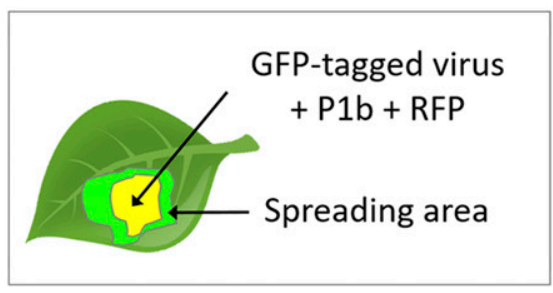

GFP

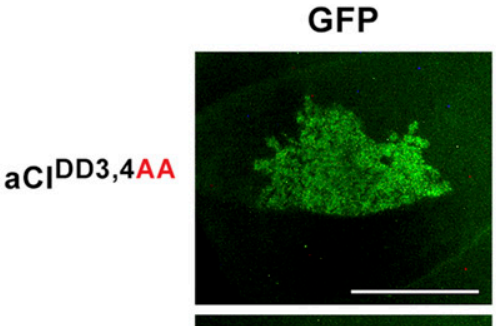

$\mathrm{aCI}^{\mathrm{DD} 3,4 \mathrm{AA}}$

aCP
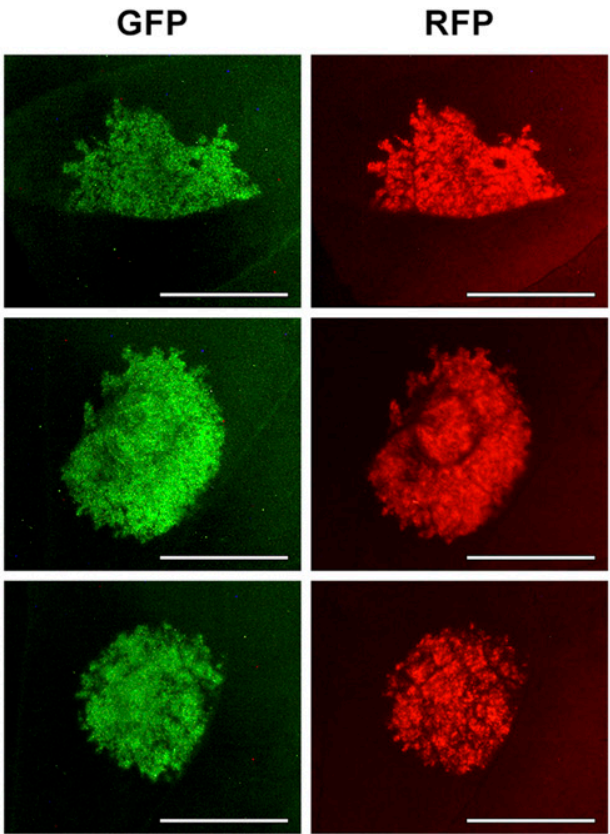

$\operatorname{aCP}^{\mathrm{T} 313 \mathrm{D}}$
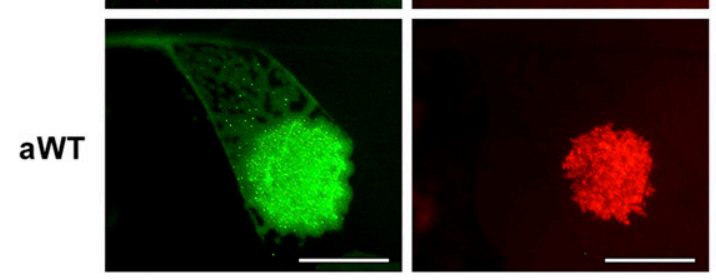
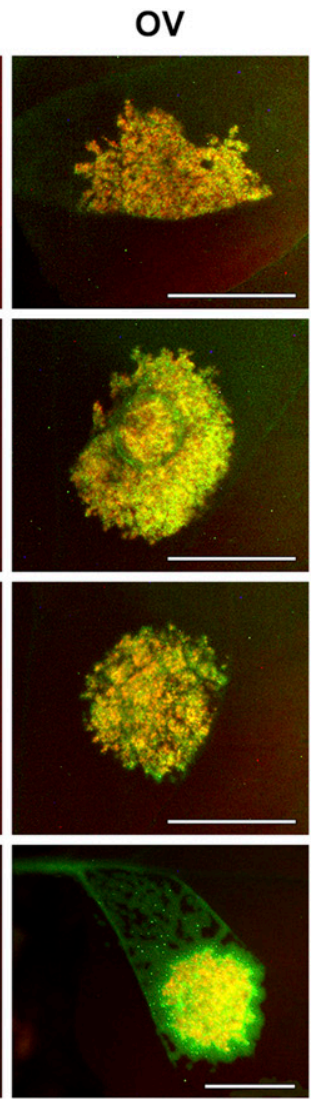

Fig. 3. Agroinfiltration of Nicotiana benthamiana leaves with plum pox virus (PPV) mutants bearing changes emulating a constitutive phosphorylation at threonine 254 (plasmid aCP ${ }^{\mathrm{T} 254 \mathrm{D}}$ ) or threonine 313 (plasmid aCP ${ }^{\mathrm{T} 313 \mathrm{D}}$ ) in the coat protein. Nonmutated wild-type PPV (aWT) and a movementdeficient cylindrical inclusion $(\mathrm{CI})$ mutant (plasmid aCI ${ }^{\mathrm{DD} 3,4 \mathrm{AA}}$ ) were included as positive and negative short-distance movement controls, respectively. Plants were agroinfiltrated in a small patch, with a mixture containing the different green fluorescent protein (GFP)-tagged viral constructs, along with plasmids expressing the P1b RNA-silencing suppressor and the red fluorescent protein (RFP). A schematic representation of possible outputs of the experiment is depicted on the left side. Leaves inoculated with the indicated viruses were collected at 7 days postinoculation, and images around the infiltration area taken with appropriate filters under an epifluorescence microscope. Assay was carried out in duplicate, rendering similar results in both cases. Scale bars $=5$ mm; $\mathrm{OV}=$ overlapping signals. 
Phospho-mimicking in specific residues at distal core of PPV CP prevents accurate virion assembly.

Having observed that phospho-mimicking mutants $\mathrm{CP}^{\mathrm{T} 254 \mathrm{D}}$ and $\mathrm{CP}^{\mathrm{T} 313 \mathrm{D}}$ fail on cell-to-cell movement, we decided to analyze whether a defect on viral assembly could be responsible for this failure.

In order to determine whether the $\mathrm{CP}^{\mathrm{T} 254 \mathrm{D}}$ and $\mathrm{CP}^{\mathrm{T} 313 \mathrm{D}}$ mutants are able to form viral particles, cell-free extracts from leaves agroinoculated with these mutants and appropriate controls were fractionated by centrifugation in sucrose gradients and separated fractions were subjected to anti-CP immunoblot analysis. To avoid distortions due to the presence of compensatory mutations detected in the virus populations of systemically infected tissues, the analysis only included inoculated leaves from those plants that were not systemically infected. We included, as a negative control in this experiment, the replication-deficient $\mathrm{CI}^{\mathrm{KS} 91,92 \mathrm{AA}}$ mutant, which does not form virus particles as a consequence of the link that couples RNA replication and virion assembly (Gallo et al. 2018).

As expected, the WT positive control showed CP signals along intermediate fractions 6 and 7, which are expected to host virions (Fig. 5). In contrast, and similarly to the $\mathrm{CI}^{\mathrm{KS} 91,92 \mathrm{AA}}$ negative control, no virus-like particles were detected in extracts of plants infected with either of the two phosphomimicking mutants for which $\mathrm{CP}$ signals were confined to top fractions (10 and 11), normally containing small viral complexes and free CP (Fig. 5). Curiously, in the case of the mutant $\mathrm{CP}^{\mathrm{T} 313 \mathrm{D}}$, the observation of faint bands displaced toward intermediate fractions suggests a vague propensity to assemble, completely abolished for $\mathrm{CP}^{\mathrm{T} 254 \mathrm{D}}$ (Fig. 5).

Our results suggest that mimicking of constitutive phosphorylations at the distal core of PPV CP precludes viral assembly and could explain, at least in part, the inability of $\mathrm{CP}^{\mathrm{T} 254 \mathrm{D}}$ and $\mathrm{CP}^{\mathrm{T} 313 \mathrm{D}}$ mutants to conduct cell-to-cell movement.

\section{Phosphorylations at $\mathrm{N}$ - and C-terminal arms} of the PPV core region may establish functional links.

The emergence of the $\mathrm{T} 254 \mathrm{~K}$ change in plants inoculated with the 4SD mutant suggests this spontaneous mutation has a long-range impact, compensating deleterious effects specific

(a)

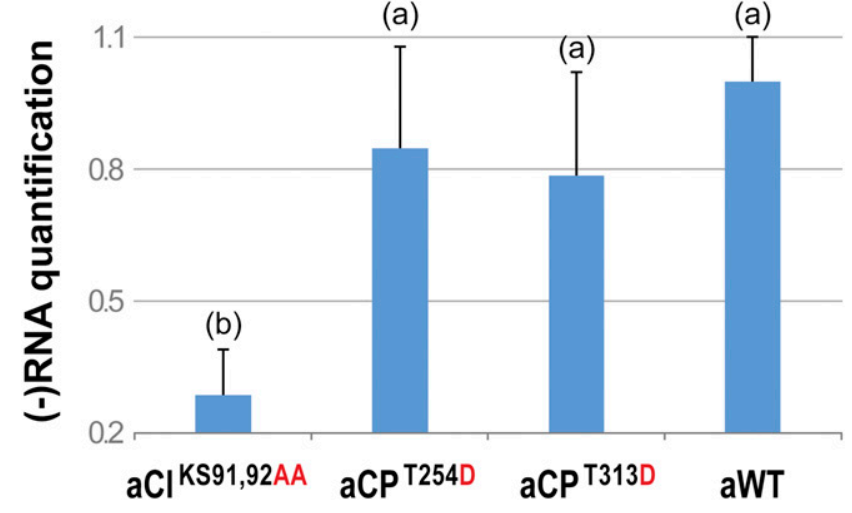

Fig. 4. Quantification of viral negative RNA strand. Nicotiana benthamiana plants were agroinoculated with mutant constructs $\mathrm{aCP}^{\mathrm{T} 254 \mathrm{D}}$ or $\mathrm{aCP}^{\mathrm{T} 313 \mathrm{D}}$ and infiltrated leaves were collected at 5 days postinoculation. The replication-deficient mutant $\mathrm{CI}^{\mathrm{KS} 91,92 \mathrm{AA}}$ (construct $\mathrm{aCI}^{\mathrm{KS} 91,92 \mathrm{AA}}$ ) and the nonmutated virus (construct aWT) were used as negative and positive control, respectively. Amount of viral negative RNA strand was quantified by reverse transcription-quantitative PCR and the ratio values with reference to wild-type PPV were plotted. Line graph shows mean \pm standard deviation ( $n=3$ biological replicates of two plants each, from two independent Agrobacterium cultures). Statistical significance $P<0.01$ was determined by a one-way analysis of variance and Bonferroni posthoc test. Different lower case letters indicate different groups. to the multiple phospho-mimicking mutant (Martínez-Turiño et al. 2018).

However, such a compensation appears not to be highly effective, since, when $N$. benthamiana plants were inoculated with an extract of infected plants in which the $4 \mathrm{SD}^{\mathrm{T} 254 \mathrm{~K}}$ mutant was selected, the virus further evolved, in three of the five inoculated plants, by reverting one of the mutations of the 4SD virus to a nonphosphorylatable condition (D118N) but still maintaining the T254K mutation (Martínez-Turiño et al. 2018).

We wanted to determine whether the compensatory mutation $\mathrm{T} 254 \mathrm{~K}$ provides an advantage only in the context of the 4SD background or also in the context of the WT virus. Moreover, we also aimed to ascertain if, after the arising of the second spontaneous mutation, D118N, the initial T254K mutation is still advantageous. To this end, appropriate competition experiments were carried out (Fig. 6). First, we engineered the T254K mutation in the WT cDNA clone pICPPV-NK-1GFP (Supplementary Fig. S2). The resulting clone $\left(\mathrm{CP}^{\mathrm{T} 254 \mathrm{~K}}\right)$ was manually inoculated in $N$. benthamiana plants, developing a PPV infection indistinguishable from that of the WT virus (data not shown). Then, extracts of $\mathrm{CP}^{\mathrm{T} 254 \mathrm{~K}}$ - and WT PPV-infected plants were mixed in order to obtain an inoculum containing both viruses in a 1.1:1 ratio, which was used to inoculate $N$. benthamiana plants. Similarly, $N$. benthamiana plants were challenged with a mixture of extracts of 4SD-inoculated plants in which the viral progeny had incorporated the $\mathrm{T} 254 \mathrm{~K}$ and D118N mutations (4SD ${ }^{\mathrm{D} 118 \mathrm{~N}+\mathrm{T} 254 \mathrm{~K}}$ ) or only the D118N mutation $\left(4 \mathrm{SD}^{\mathrm{D} 118 \mathrm{~N}}\right)$ (Martínez-Turiño et al. 2018), also adjusted to achieve a 1.1:1 ratio of viruses (Fig. 6).

In the competition of WT vs. $\mathrm{CP}^{\mathrm{T} 254 \mathrm{~K}}$, the nonmutated virus, despite its slightly lesser amount, was recovered alone in three of the four plants inoculated with the mixture, while both viruses were detected coexisting just in one plant. Thus, the change $\mathrm{T} 254 \mathrm{~K}$ does not provide any competitive advantage when it is together with the WT S118 residue (Fig. 6, left side). Similarly, in the confrontation $4 \mathrm{SD}^{\mathrm{D} 118 \mathrm{~N}}$ vs. $4 \mathrm{SD}^{\mathrm{D} 118 \mathrm{~N}+\mathrm{T} 254 \mathrm{~K}}$, the double mutant, in spite of being slightly overrepresented in the inoculation mixture, was not able to impose itself in any of four inoculated plants. Indeed, in one of all these plants, $4 \mathrm{SD}^{\mathrm{D} 118 \mathrm{~N}}$ was detected all alone (Fig. 6, right side). Thus, $\mathrm{T} 254 \mathrm{~K}$ does not provide a competitive advantage to the virus, either, when position 118 is occupied by the nonphosphorylatable residue asparagine.

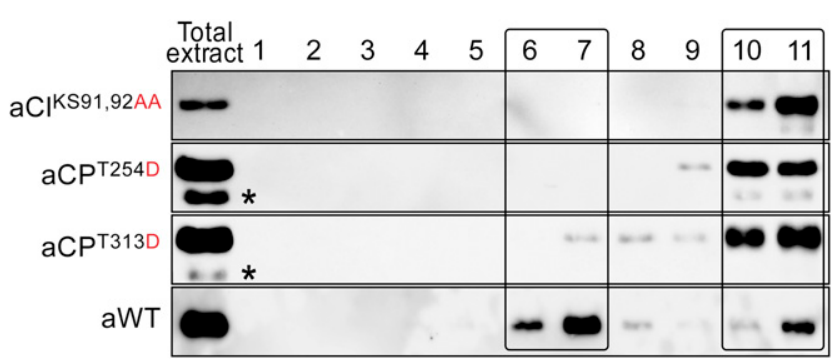

Fig. 5. Assessment of viral particle formation. Nicotiana benthamiana plants were agroinoculated with the mutant constructs $\mathrm{aCP}^{\mathrm{T} 254 \mathrm{D}}$ or $\mathrm{aCP}^{\mathrm{T} 313 \mathrm{D}}$ and infiltrated leaves were collected at 5 days postinoculation. A replication-deficient CI mutant, also unable to form virions (construct $\mathrm{aCI}^{\mathrm{KS} 91,92 \mathrm{AA}}$ ), and the wild-type virus (construct aWT) were used as negative and positive control, respectively. Cell-free extracts from infiltrated leaves were fractioned by centrifugation in a sucrose gradient and were subjected to anti-capsid protein (CP) immunoblot analysis. Total nonfractionated extract and fractions from the bottom (column 1) to the top (column 11) of the gradient are shown. Fractions normally retaining small complexes and free CP (columns 10 and 11) and virus-like particles (columns 6 and 7) appear framed. Asterisks (*) highlight a degradation band, consequence of nonassembled CP instability. 
CP instability caused by constitutive phospho-mimicking at the $\mathrm{N}$-terminal region of the protein can be partially reversed by a distant compensatory mutation.

We previously reported that emulation of constitutive phosphorylation at the N-terminal side of PPV CP, engineered in the 4SD mutant, reduced in-vitro protein stability (Martínez-Turiño et al. 2018). We wondered whether spontaneous mutation $\mathrm{T} 254 \mathrm{~K}$, emerged in 4SD-infected plants, could correct this stability defect. To address this question, $\mathrm{CP}$ from $4 \mathrm{SD}^{\mathrm{T} 254 \mathrm{~K}}$ mutant was subjected to an endogenous degradation assay in parallel with that of the 4SD mutant. After $1 \mathrm{~h}$ of incubation in cell-free extracts at $25^{\circ} \mathrm{C}, \mathrm{CP}$ of $4 \mathrm{SD}^{\mathrm{T} 254 \mathrm{~K}}$ was detected at a higher level than that of the 4SD sample, and, after $2 \mathrm{~h}$ of incubation, the difference widened further (Fig. 7A). The fact that a stability defect caused by mutations in the $\mathrm{CP} \mathrm{N}$-terminal region can be reversed by a change in the $\mathrm{C}$-terminal region further supports the existence of remote functional connections between both regions of the protein.

To inquire why phospho-mimicking at the protein N-terminal half causes detrimental effects on PPV infection and CP stability, putative structural alterations of 4SD virions were explored by analyzing their morphology, by immunosorbent electron microscopy (ISEM), and their sedimentation properties, by centrifugation in sucrose gradients.
Cell-free extracts were prepared from WT PPV- and 4SDinfected $N$. benthamiana plants. 4SD viral progeny was previously analyzed by RT-PCR amplification and sequencing to ensure absence of spontaneous reversions or second mutations into the $\mathrm{CP}$ sequence. Extracts were subjected to ISEM and were fractionated by centrifugation in a sucrose gradient, followed by anti-CP immunoblot analysis immediately after its preparation $(t=0)$ and after incubation at $25^{\circ} \mathrm{C}$ for $60 \mathrm{~min}(t=$ 60) (Fig. 7B and C).

4SD virions detected by ISEM in nonincubated extracts were similar to those of WT virus. In contrast, observation of some ISEM grids from 1-h-incubated 4SD samples $(t=60)$ ( $\operatorname{six}$ of 18 grids from three independent experiments) revealed the presence of deformed particles coexisting with apparently normal particles. Weird particles were never observed in WT samples, regardless of the elapsed incubation time prior to analysis (Fig. 7B). Analysis by $2 \times 2$ Fisher exact test of data from three biological replicates of WT and the 4SD mutant, taken at $t=0$ and $t=60$, showed strong statistical significance for occurrence of noncanonical viral particles in 4SD mutant at $t=60(P$ value $<0.00001)$.

Additionally, extracts were subjected to sucrose gradient centrifugation. In line with ISEM results, although $t=0$ samples of 4SD and WT virus showed some differences at gradient top
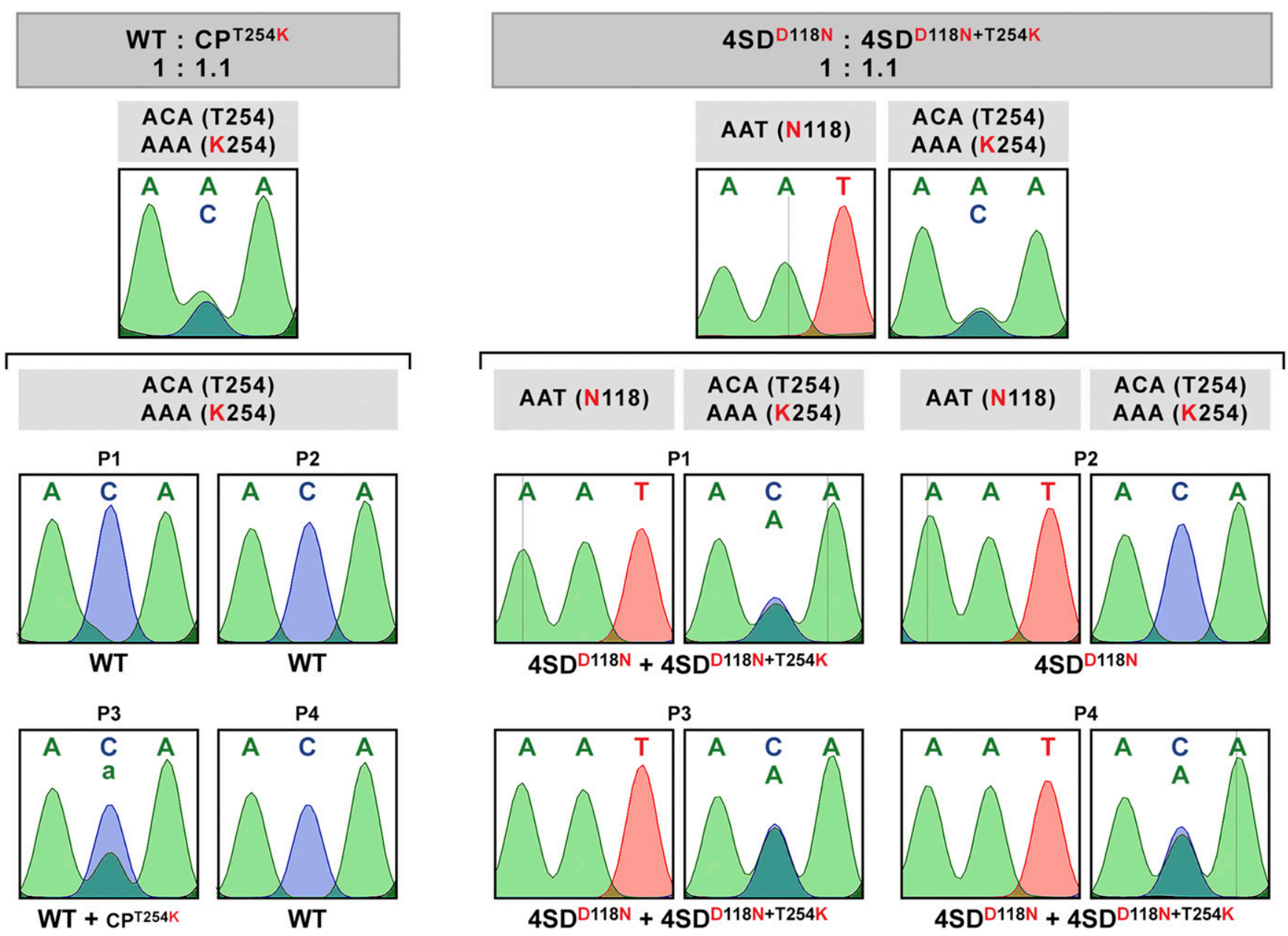

Fig. 6. Sequence analysis of viral progeny from mixed infections with competing viruses. Viral titers in extracts obtained from Nicotiana benthamiana plants infected with each virus were determined by Western blot. On the basis of capsid protein (CP) quantification, amounts of extracts were adjusted to get a 1.1:1 ratio of both competitors. Inoculums, containing wild-type (WT) and $\mathrm{CP}^{\mathrm{T} 254 \mathrm{~K}}$ (left) or $4 \mathrm{SD}^{\mathrm{D} 118 \mathrm{~N}}$ and $4 \mathrm{SD}^{\mathrm{D} 118 \mathrm{~N}+\mathrm{T} 254 \mathrm{~K}}$ (right), were used to inoculate four $N$. benthamiana plants. Viral progeny were analyzed in individual plants (P1 to P4) by reverse transcription-PCR (RT-PCR) and sequencing of a cDNA fragment covering the $\mathrm{CP}$ coding region. Images show the chromatograms of codons 118 (AAT for asparagine in $4 \mathrm{SD}^{\mathrm{D} 118 \mathrm{~N}}$ and $4 \mathrm{SD}^{\mathrm{D} 118 \mathrm{~N}+\mathrm{T} 254 \mathrm{~K}}$ ) and 254 (ACA for threonine in WT and $4 \mathrm{SD}^{\mathrm{D} 118 \mathrm{~N}}$, or AAA when threonine changed to lysine in $\mathrm{CP}^{\mathrm{T} 254 \mathrm{~K}}$ or $\left.4 \mathrm{SD}^{\mathrm{D} 118 \mathrm{~N}+\mathrm{T} 254 \mathrm{~K}}\right)$. Viruses identified are indicated beneath the chromatograms; smaller letters indicate lower accumulation. 
fractions (fractions 16 to 18 ), they displayed very similar internal gradient profiles, revealing viral particles sedimenting at fractions 9 to 11 . More conspicuous, whereas sedimentation profile of WT particles was slightly affected by in-vitro incubation, a peak of 4SD virions in 1-h-incubated extracts was notably shifted toward bottom fractions of the gradient, indicating a certain increase in the sedimentation coefficient of those viral particles (Fig. 7C). ISEM analysis detected WT-like particles at different internal fractions of 4SD gradient (data not shown), suggesting that weird particles observed in unfractionated extract were lost during centrifugation procedure.

Next, we evaluated whether spontaneous mutations T254K and D118N, likely emerging to compensate for defects of the 4SD mutant, are able to correct the distorted structure of 4SD

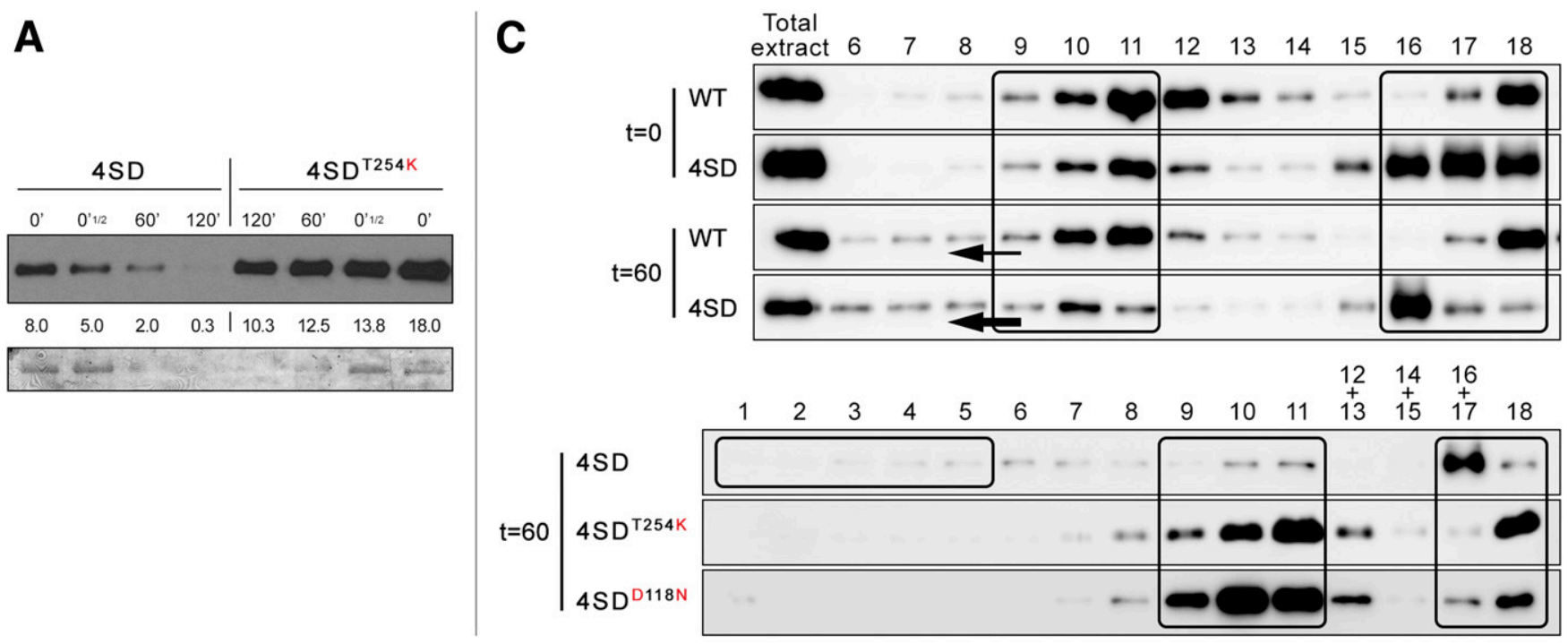

B

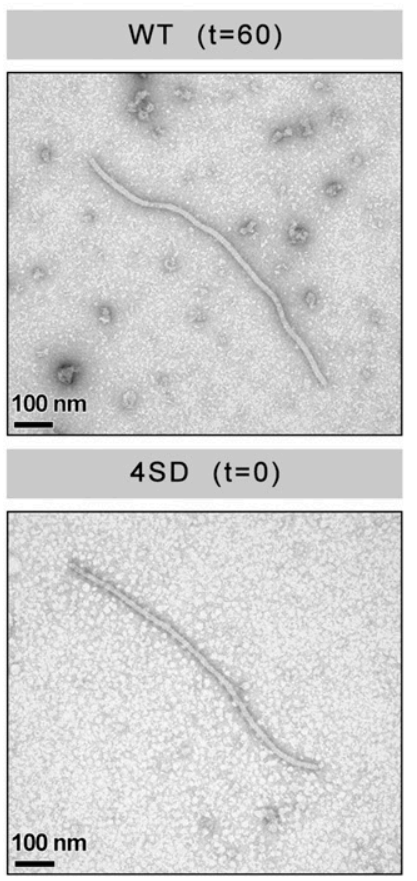

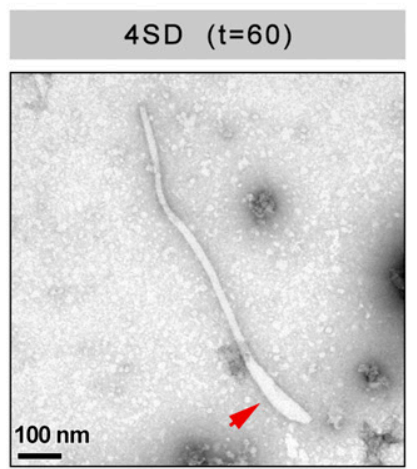
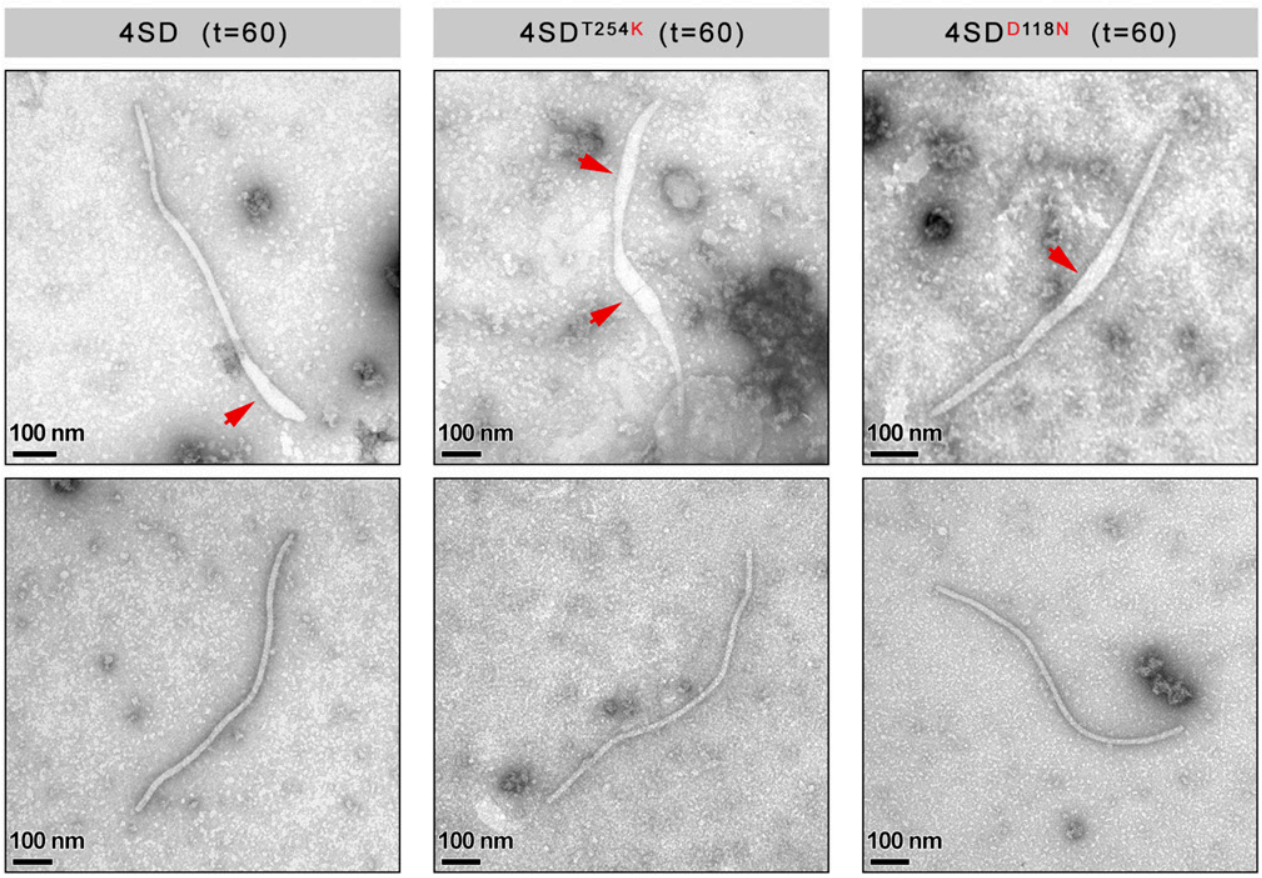

Fig. 7. Disturbances of plum pox virus (PPV) virions caused by phospho-mimicking mutations. A, Effect of the potentially compensatory mutation T254K on the capsid protein $(\mathrm{CP})$ stability of the phospho-mimicking multiple mutant 4SD. Native extracts were prepared from systemically infected leaves, collected at 21 days postinoculation, of Nicotiana benthamiana plants inoculated with leaf extracts harboring the intact 4SD mutant or a virus variant that had incorporated the additional T254K mutation $\left(4 \mathrm{SD}^{\mathrm{T} 254 \mathrm{~K}}\right)$. CP accumulation was assessed in these extracts by immunoblot analysis immediately after homogenization $\left(0^{\prime}\right.$ and $0^{\prime} 1 / 2$, in which a half amount of sample was loaded) or after incubation during indicated times. Intensity values of CP bands were calculated with Quantity One 1-D software (Bio-Rad) and are shown below each lane. Blots stained with Ponceau red showing the ribulose-1,5-bisphosphate carboxylase/oxygenase protein are included as loading control. B, The same extracts as well as extracts from systemically infected tissue of 4SD-inoculated plants harboring a virus variant that had incorporated the additional $\mathrm{D} 118 \mathrm{~N}$ mutation $\left(4 \mathrm{SD}^{\mathrm{D} 118 \mathrm{~N}}\right)$ were subjected to immuno-absorbent electro-microscopy and $\mathbf{C}$, fractionation by centrifugation in a sucrose gradient (10 to $40 \%$ ) immediately after homogenization $(t=0)$, after incubation at $25^{\circ} \mathrm{C}$ for 60 min $(t=60)$, or both. Most seriously deformed regions in anomalous viral particles are indicated with red arrowheads. For the sucrose gradient sedimentation assay, aliquots, collected from bottom to top (1 to 18) were loaded individually or after mixing two of them and were subjected to anti-CP immunoblot analysis. Fractions containing particles with highest sedimentation speed (fractions 1 to 5), hosting virus-like particles (fractions 9 to 11), and small complexes or free CP (fractions 16 to 18) are framed Horizontal arrows of different thicknesses symbolize varying shift of virus-like particles toward the bottom of the gradient. Absence of unintended mutations was verified for all analyzed extracts by reverse transcription-PCR (RT-PCR) and sequencing. 
virions. Systemically infected leaves of $N$. benthamiana plants inoculated with 4SD mutant, whose viral progeny had incorporated either mutation $\mathrm{D} 118 \mathrm{~N}$ or $\mathrm{T} 254 \mathrm{~K}$, were used to prepare cell-free extracts, and then, incubated at $25^{\circ} \mathrm{C}$ for $60 \mathrm{~min}$.

As previously observed in 4SD samples, ISEM images disclosed the presence of deformed particles at variable proportions in extracts containing viruses $4 \mathrm{SD}^{\mathrm{D} 118 \mathrm{~N}}$ (in one of eight analyzed grids) or $4 \mathrm{SD}^{\mathrm{T} 254 \mathrm{~K}}$ (in one of four analyzed grids). Also, in these samples, anomalous particles coexisted with normalappearing particles (Fig. 7B). However, sucrose gradient sedimentation profiles of both spontaneous mutants resembled that of WT virions instead of the profile of the 4SD mutant from which they derived (Fig. 7C). Also, these results suggest that either in-situ or distant spontaneous mutations partially compensate for defects caused by constitutive phosphorylation at the $\mathrm{N}$-terminal part of the protein and show that some functional crosstalk could be operating between distant regions of PPV CP.

\section{Modeling of PPV virion structure supports the contribution of phospho-targets to interchain protein-protein interactions.}

Recently, capsid structures of three potyviruses, watermelon mosaic virus (WMV) (Zamora et al. 2017), potato virus Y (Kežar et al. 2019), and turnip mosaic virus (Cuesta et al. 2019), have been solved by cryo-electron microscopy. These atomic structures show a conserved fold for CPs of flexuous filamentous plant viruses and constitute an excellent starting point to perform structural inferences for other potyviruses, including PPV.

The structure of the WMV CP solved by Zamora et al. (2017) supports the idea that potyviral CPs consist of three main domains, delimiting the core domain between residues that correspond to PPV amino acids 109 and 314, flanked by nonstructured or flexible $\mathrm{N}$ - and C-terminal extensions (Supplementary Fig. S3). Our results suggest the existence of a functional crosstalk between two of the phospho-targets of PPV $\mathrm{CP}, \mathrm{S} 118$ and T254, located at proximal and distal regions of the protein core, respectively. To get information about spatial distribution of both residues, a model for PPV CP monomer was obtained, based on the atomic structure of the core of WMV $\mathrm{CP}$, available at the Protein Data Bank (PDB) (accession 5ODV). The first 108 residues of the N-terminal region of PPV $\mathrm{CP}$, hosting three of the four previously mapped phosphorylatable serines $(\mathrm{pS} 25, \mathrm{pS} 81$, and $\mathrm{pS} 101)$ and two of the four recently found phosphorylatable threonines (pT71 and pT106), were left out of modeled monomer. Conveniently, the greatestimpact phosphorylation target at the proximal core $(\mathrm{pS} 118)$ and another two threonines prone to phosphorylation at the distal core (pT254 and pT313) could be included in the PPV model (Supplementary Fig. S3).

Comparative modeling for the PPV CP monomer was obtained with I-TASSER (Yang et al. 2015) (Supplementary Fig. S4). Prediction accuracy was validated according to quality parameters C-score (1.77), TM-score $(0.96 \pm 0.05)$, and RMSD $(0.20 \pm 0.16 \mathrm{~nm})$. Next, a PPV oligomeric complex was obtained by rigid-body fitting of PPV monomer on each of the subunits of the WMV oligomer.

Spatial distribution adopted by the different PPV CP monomers suggests that serine 118 , located at the greater-flexibility $\mathrm{N}$-terminal arm of the core, poorly solved in WMV CP and poorly modeled in PPV CP, could participate in interactions occurring on the outer surface of viral particle, while threonine 254 could do it in those taking place inside the virion (Fig. 8A). Thus, PPV modeled structure does not support the hypothesis of physical interactions between phosphorylatable residues S118 and T254 that could account for the suggested functional crosstalk. Hence, we analyzed those residues involved in interactions stabilizing WMV oligomer, comparable to PPV virion (discussed below).

For WMV virions, data available online from the PDBSum tool predict one salt bridge and eight hydrogen bonds are involved in interactions between CP monomers within the same helix turn. Additionally, three salt bridges and ten hydrogen bonds are proposed to stabilize interactions between chains of adjacent helix turns (Table 1; Fig. 8A). In addition, it was predicted that a large number of nonbonded contacts would stabilize the monomer interfaces (Table 1). Of note, one of eight hydrogen bonds and five nonbonded contacts between chains of the same helix turn predicted in the WMV virion involve residue N68, equivalent to phospho-target S118 of PPV CP. Residue interacting with WMV N68 is an aspartic, D178, whose PPV counterpart is N228. Furthermore, the only predicted salt bridge between chains of the same helix turn involves R204 (interacting with E228), equivalent to another PPV phosphorylatable residue, T254, which mutates to K, apparently to compensate S118D mutation (discussed above). R204 is also predicted to participate in two hydrogen bonds and ten nonbonded contacts between chains of same helix turns (interacting with residues N224 and E228) and in one hydrogen bond and four nonbound contacts between chains of adjacent helix turns (interacting with L245) (Table 1; Fig. 8B). Obviously, interactions N68:D178, R204:E228, R204:N224, and R204:L245 cannot happen among the equivalent couples (S118:N228, T254:E278, T254:V274, and T254:L295) in nonmodified PPV virions. However, it is tempting to guess they can be established when S118 becomes phosphorylated or replaced by an aspartic residue and when threonine at position 254 spontaneously mutates to lysine (Fig. 8B).

Additional evidence indirectly supporting a putative role of phospho-target S118 in virion stabilization came from involvement in several nonbonded contacts between chains within the same helix turn of a residue of WMV CP (R187), equivalent to PPV CP R237, which spontaneously mutates to Q as part of the evolution of the 4SD phospho-mimicking mutant (mutation 4SD ${ }^{\mathrm{D} 118 \mathrm{~N}+\mathrm{R} 237 \mathrm{Q}}$ ) (Table 1).

Residue T263 of WMV CP, equivalent to phospho-target T313 of PPV CP, is not proposed to be involved in interchain contacts. However, certain contribution of T313 to interactions between virion subunits can be surmised once second mutations at positions E235 or T254, which implies a +1 gain in the net charge of the protein, are selected in the progeny of $\mathrm{CP}^{\mathrm{T} 313 \mathrm{D}}$ mutant (discussed above). Such mutated residues match with amino acids E185 and R204, which are involved in interactions within the WMV virion (Table 1). This would be in accordance with the role proposed for the phospho-target T313 in PPV virion assembly evidenced by biochemical analyses.

\section{DISCUSSION}

Phosphorylation is a PTM frequently contributing to the regulation of functions of different types of viral proteins. This is often the case of $\mathrm{CP}$ proteins of DNA and RNA viruses both of animals and plants (Hoover and Kao 2016; Ivanov and Mäkinen 2012; Keating and Striker 2012).

Precise mapping of phosphorylatable residues has been conducted only for a few viral CPs, but available data suggest that, although some CPs appear to be phosphorylated primarily in a single residue, complex patterns of phosphorylation could be more common (Champagne et al. 2007; Hipp et al. 2019; Hoover et al. 2016; Ivanov et al. 2003; Zhao et al. 2015). This also applies to the PPV CP. Initial matrix-assisted laser desorption-ionization TOF results and immunoblot analyses combined with phosphatase treatments showed that a large 
fraction of the PPV CP was phosphorylated in at least one residue (Chen et al. 2005; Šubr et al. 2007, 2010), and further MS analyses identified four major phosphorylation targets in the N-terminal protrusion and upper-core region of the protein (Martínez-Turiño et al. 2018). Results provided in this paper show an even more complex scenario for PPV CP phosphorylation, wherein the modification is also affecting residues in the C-terminal half of the protein (Fig. 1C).

Functions of CP phosphorylation appear to be important for RNA virus infection and are quite diverse. Frequently, addition of the negative charge of phosphate residues disturbs CP RNAbinding activity, which has been suggested would facilitate translational activation of the encapsidated RNA of the potexvirus PVX (Atabekov et al. 2001), regulate the timing of expression of the different genome fragments of the bromovirus BMV (Hoover et al. 2016), and affect symptom recovery of the cucumovirus CMV (Nemes et al. 2019). Modulation of RNAbinding activity by phosphorylation of the $\mathrm{CP}$ of another potexvirus, BaMV, has been shown to regulate cell-to-cell virus movement (Hung et al. 2014). Systemic movement of the necrovirus BBSV also appears to depend on phosphorylation of the viral CP; however, in this case, the PTM is involved in the formation of stable virions with little effect on RNA binding activity (Zhao et al. 2015).

$\mathrm{CP}$ phosphorylation is also relevant for viral replication. This has been reported for different animal viruses (Law et al. 2003; Li et al. 2018; Mondal et al. 2015; Ranadheera et al. 2018), and it has been extensively studied for the plant potyvirus PVA (Lõhmus et al. 2017). In this last case, it has been suggested that the nonphosphorylated $\mathrm{CP}$ binds to the viral RNA, stopping translation; next, CK2 kinase-mediated phosphorylation of PVA CP promotes its ubiquitination and degradation, facilitating the assembly of viral replication complexes. Requirement of both phosphorylated and nonphosphorylated versions of the protein justifies the drastic deleterious effects on viral replication caused by either phospho-deficient or phosphomimicking mutations in the CK2 motif of PVA CP (Lõhmus et al. 2017). This contrasts with phosphorylation of the CP of PPV, a potyvirus like PVA, both in previously reported sites (Martínez-Turiño et al. 2018) and in those that have now been characterized (Figs. 2 and 3), for which constitutive phosphomimicking (mutations of $\mathrm{S}$ or $\mathrm{T}$ to $\mathrm{D}$ ) has a much more drastic effect than phosphorylation prevention (mutations of $\mathrm{S}$ or $\mathrm{T}$ to A).

Although the CK2-recognition site of PVA CP appears to be conserved at an equivalent place of the $\mathrm{C}$-terminal region of PPV CP $\left({ }^{303}\right.$ GTQEED $\left.^{308}\right)$, the phosphorylations mapped in the carboxyl moiety of this last protein reported now were detected in surroundings out of the CK2 motif (T254 and T313), and, unlike the phosphorylation of PVA CP, were found in $\mathrm{CP}$ assembled in virions. In addition, whereas disturbance of CK2mediated phosphorylation of PVA CP prevent viral RNA replication, mimicking constitutive phosphorylation at residues 254 and 313 of PPV CP does not affect viral replication but, rather, cell-to-cell movement. Thus, it is unlikely that the proposed model for the function of phosphorylation of PVA CP could be applicable to PPV CP. Our results clearly demonstrate the relevance of residues T254 and T313 for virion formation,

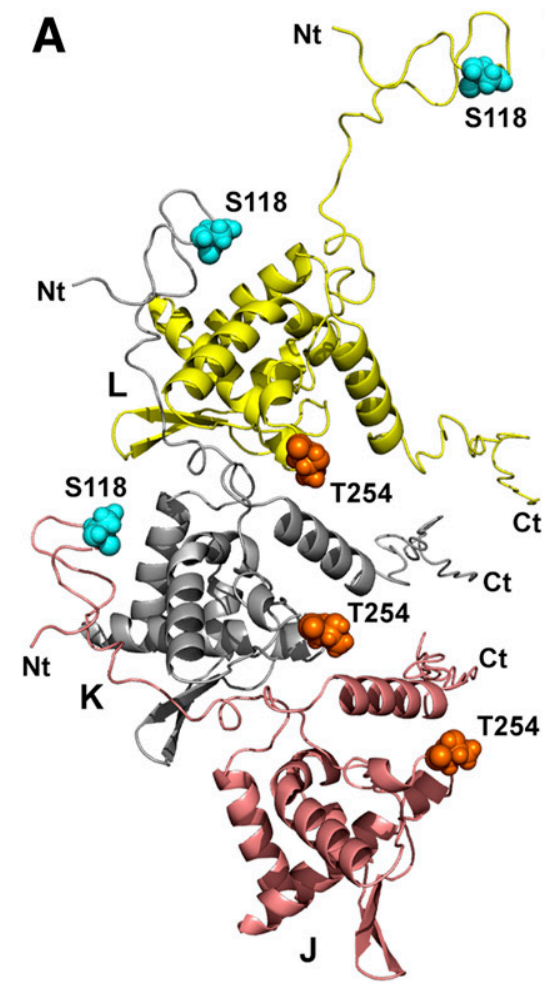

B
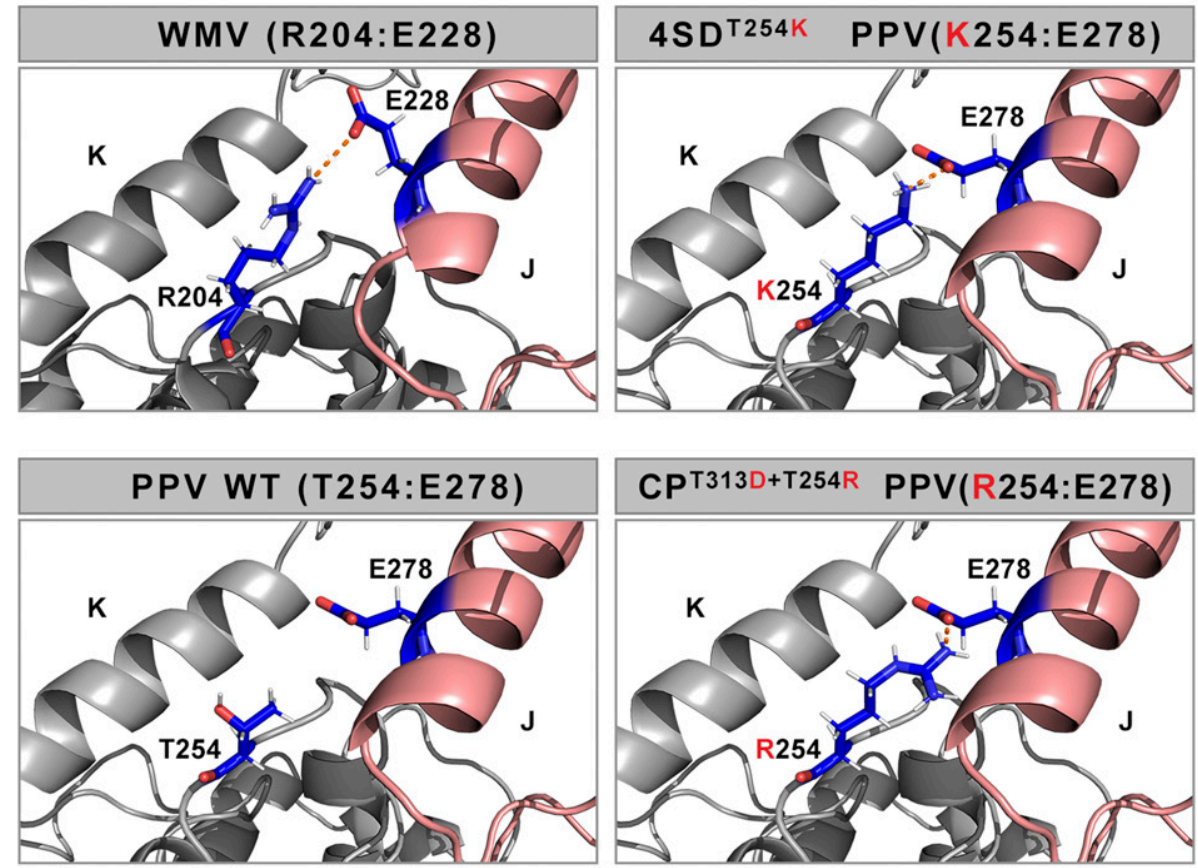

Fig. 8. A, Cartoon representation of a fragment of the in silico model obtained for the oligomeric complex formed by the plum pox virus (PPV) capsid protein (CP). Image shows clockwise disposition of three CP monomers: J chain (light salmon), K chain (gray), and L chain (yellow) in the same helix turn. N-terminal $(\mathrm{Nt})$ and $\mathrm{C}$-terminal $(\mathrm{Ct})$ regions of each monomer as well as residues prone to phosphorylation, S118 (cyan sphere), on the outside surface of the viral particle, and T254 (orange sphere), inside the cylinder, are also indicated. B, Salt bridge predicted in the atomic model of watermelon mosaic virus (WMV) (Zamora et al. 2017), occurring between residues arginine 204 in K chain (gray) and glutamic acid 228 in J chain (salmon), which stabilizes interfaces between monomers of CP in the same helix turn. Such a salt bridge could not occur between equivalent residues (threonine 254 , K chain, and glutamic acid $278, \mathrm{~J}$ chain) in the PPV wild-type oligomer. Permanent phospho-mimicking at serines $25,81,101$, and 118 (4SD mutant) or at threonine 313 (CP ${ }^{\mathrm{T} 313 \mathrm{D}}$ mutant) of PPV CP promote spontaneous mutations changing threonine 254 to lysine $\left(4 \mathrm{SD}^{\mathrm{T} 254 \mathrm{~K}}\right)$ or to arginine $\left(\mathrm{CP}^{\mathrm{T} 313 \mathrm{D}+\mathrm{T} 254 \mathrm{R}}\right)$, respectively, allowing, in both cases, the formation of a salt bridge (K254:E278 or R254:E278). PyMOL cartoon zoom views are shown, including interacting residues (stick representation) and distance measurements less than $0.4 \mathrm{~nm}$ that allow a salt bridge binding. 
and modeling of PPV particles from the experimentally determined structure of WMV virions suggests these two phosphorylatable amino acids are not directly involved in interactions with the RNA (Fig. 5; Table 1).

We do not know if PPV CP is phosphorylated at T254 and T313 before or after assembly in the viral particles. We also ignore what is the proportion of $\mathrm{CP}$ molecules phosphorylated at these residues in the PPV virions, although MS data suggest most assembled CP molecules might be nonphosphorylated.

What we know from phenotypes of T254A and T313A mutants is that phosphorylation at threonines 254 and 313 is not essential for virion assembly, whereas the inability of phosphomimicking T254D and T313D mutants to make virus particles suggests that excessive phosphorylation at these residues is detrimental for virion stability. An appealing interpretation of these data is that, although nonphosphorylated PPV particles are functional, certain instability provided by the phosphorylation of amino acids involved in the virion structure maintenance could facilitate the uncapsidation of the genomic RNA required to start a new round of infection.

In a previous work, the phosphorylation of S118 was analyzed together with that of three other serines of the N-terminal half of PPV CP (S25, S81, and S101) (Martínez-Turiño et al. 2018). Results from that paper showed that these phosphorylations are not essential but make some contribution to viral fitness. Mimicking phosphorylation at S118 appeared to be especially detrimental, and emergence of putative compensating mutations at the $\mathrm{CP} \mathrm{C}$-terminal moiety suggested the existence of long-distance interactions operating in the protein, likely modulated by phosphorylation. Our current results agree with this suggestion. Unlike phospho-mimicking at T254 or T313, emulation of phosphorylation in the four targets at the $\mathrm{N}$-terminal half of $\mathrm{CP}$ does not preclude the assembly of virions but causes disorders on them that are partially corrected by a $\mathrm{T}$ to $\mathrm{K}$ mutation at position 254 (Fig. 7). The accuracy of the in silico modeling of PPV CP, based on the structure of the WMV virion established by cryoEM, is not sufficient to allow a precise characterization of the effect of phosphorylation on intraand intermolecular interactions between $\mathrm{CP}$ monomers in the viral particle, but the model points to S118, T254, and T313 as residues likely involved in interactions contributing to maintain the virion structure, which could be modulated by phosphorylation (Fig. 8; Table 1). S25, S81, and S101 are located in the $\mathrm{N}$-terminal protrusion of PPV CP, whose counterpart in the PPV WMV could not be resolved (Zamora et al. 2017) and is thought to remain exposed outside the potyviral particles (Shukla et al. 1988). Thus, we do not think phosphorylation in these residues contribute to the modulation of the stability of viral particles. Rather, we contemplate a scenario in which dynamic phosphorylation and $O$-GlcNAcylation of the PPV CP N terminus affect protein susceptibility to the cellular proteolytic machinery, probably to the ubiquitin proteasome system, as previously suggested (Martínez-Turiño et al. 2018). This would enable fine-tuning of protein stability, thus providing the appropriate amount of $\mathrm{CP}$ for each phase of the viral infection.

The defect in viral movement of T254D and T313D phosphomimicking mutants appears to be a secondary effect of the inability to form viable viral particles (Figs. 3 and 5). This agrees with previous reports showing that mutations in the core region of potyviral CPs prevent virion assembly and, as a consequence, cell-to-cell movement, without affecting viral RNA replication (Dolja et al. 1994; Varrelmann and Maiss 2000). The fact that the in-vitro instability of the CP of 4SD mutant (which includes S118D mutation) was partially fixed with T254K mutation suggests this defect could also be related to a defective virion assembly rather than only to an intrinsic enhancement of the susceptibility to proteolytic degradation.

The set of results obtained here points to independent functions for phosphorylation at the N-terminal protrusion and at the proximal (S118) and distal (T254 and T313) regions of the PPV CP core. Dual functions attributed to phosphorylation in a single viral protein might be not exceptional, since this has also

Table 1. Inter-plum pox virus (PPV) capsid protein (CP) chain links involving phospho-targets S118 and T254 or spontaneously mutating R237 and E235 residues $^{\mathrm{a}}$

\begin{tabular}{|c|c|c|c|c|}
\hline Interacting chains $^{b}$ & Total bonds ${ }^{c}$ & Key bonds ${ }^{d}$ & WMV & PPV \\
\hline \multirow[t]{10}{*}{$\mathrm{K}: \mathrm{L}(26: 23 \mathrm{aa})$} & Salt bridges (1) & $1 / 1$ & R204:E2228 & $T 254: \mathrm{E} 278$ \\
\hline & Hydrogen bonds (8) & $1 / 8$ & R204:N224 & T254:V274 \\
\hline & & $1 / 8$ & R204:E228 & T254:E278 \\
\hline & & $1 / 8$ & D178:N68 & N228:S118 \\
\hline & Nonbonded contacts (101) & 8/101 & R204:N224 & $T 254: \mathrm{V} 274$ \\
\hline & & $2 / 101$ & R204:E228 & $T 254: \mathrm{E} 278$ \\
\hline & & $\mathbf{5} / 101$ & D178:N68 & N228:S118 \\
\hline & & $2 / 101$ & R187:P88 & R237:P138 \\
\hline & & $1 / 101$ & R187:Y86 & R237:Y136 \\
\hline & & $\mathbf{1} / 101$ & R187:K87 & R237:S137 \\
\hline \multirow[t]{3}{*}{$\mathrm{K}: \mathrm{S}(11: 14$ aa) } & Salt bridges (2) & - & - & - \\
\hline & Hydrogen bonds (8) & $\mathbf{1} / 8$ & L245:R204 & L295:T254 \\
\hline & Nonbonded contacts (53) & $4 / 53$ & L245:R204 & L295:T254 \\
\hline \multirow[t]{5}{*}{$\mathrm{K}: \mathrm{T}(12: 14 \mathrm{aa})$} & Salt bridges (1) & - & - & - \\
\hline & Hydrogen bonds (1) & - & - & - \\
\hline & Nonbonded contacts (43) & - & - & - \\
\hline & & $1 / 43$ & G143:E185 & G193:E235 \\
\hline & & $1 / 43$ & V144:E185 & M194:E235 \\
\hline \multirow[t]{3}{*}{$\mathrm{K}: \mathrm{U}(5: 4 \mathrm{aa})$} & Salt bridges $(0)$ & - & - & - \\
\hline & Hydrogen bonds (1) & $0 / 1$ & - & - \\
\hline & Nonbonded contacts (15) & $0 / 15$ & - & - \\
\hline
\end{tabular}

\footnotetext{
${ }^{a}$ Suggested by a homology-based structural model of PPV virions derived from the experimentally obtained watermelon mosaic virus (WMV) virion structure (Zamora et al. 2017). Interacting residues in WMV CP monomers (in bold) corresponding to PPV CP phospho-targets S118 and T254 (in italic) and those residues spontaneously changing in PPV phospho-mimicking mutants (R237 and E235, in bold italic). Equivalence between WMV and PPV CP residues was established on the basis of the sequence alignment shown in Supplementary Figure S3.

${ }^{b} \mathrm{~L}$ chain or $\mathrm{S}, \mathrm{T}$, and $\mathrm{U}$ chains are $\mathrm{CP}$ monomers, respectively, placed in the same or a different helix turn with respect to $\mathrm{K}$ chain in the virion structure.

c Number of each type of contact in the WMV virion is indicated in parentheses.

d Number of putative contacts in PPV virions involving phospho-targets S118 and T254 or spontaneously mutating R237 and E235 to the total number of predicted contacts.
} 
been described for the RNA replicase of the tymovirus TYMV (Jakubiec and Jupin 2007; Jakubiec et al. 2006). As explained above, the function of phosphorylation on PVA CP seems to be different from the two functions that we are proposing for PPV $\mathrm{CP}$ phosphorylation. This suggests that phosphorylationmediated regulation is not a general trait acquired during evolution throughout the genus Potyvirus but is, indeed, a useful tool acquired by a number of potyviruses with quite specific purposes. Although, in assays here described, none of the phospho-mimicking or abolishing $\mathrm{CP}$ mutants appear to induce symptoms of necrosis or hypersensitive response, with current available data, we cannot rule out the possibility that some phosphorylations of potyviral CPs, especially that of the $\mathrm{N}$ terminus of PPV CP, may be the result of a host defensive response rather than part of the virus amplification strategy, as it has been suggested for phosphorylation of the PEST motif of the RNA replicase of TYMV (Jakubiec et al. 2006).

\section{MATERIALS AND METHODS}

\section{Viral cDNA clones.}

PPV full-length cDNA clones of the WT PPV (pICPPV-NK1GFP) (Pérez et al. 2013), the multiple mutant bearing changes that prevent (pICPPV-NK-lGFP-4SA, 4SA) or emulate (pICPPVNK-1GFP-4SD, 4SD) phosphorylation of CP at S25, S81, S101, and S118 (Martínez-Turiño et al. 2018), were previously described.

Single mutations affecting phosphorylation target sites, threonine 254 or threonine 313 , were engineered into pICPPVNK-lGFP. Changes included the replacement of T254 (ACA) or T313 (ACC) codons by those of alanine (T254A and T313A), aspartic acid (T254D and T313D), lysine (T254K), or asparagine $(\mathrm{T} 313 \mathrm{~N})$, or by a different triplet also coding for threonine (T254T*). Mutation T254T* (ACA $\times$ ACC) was conceived to generate a distortion as strong as possible in the RNA folding while keeping the original residue.

Mutations were introduced by site-directed mutagenesis, using a two-step overlap extension PCR approach with mutagenic primers (Ho et al. 1989). Specific mutators and flanking primers are listed in the Supplementary Table S2. Fragments containing single mutations were digested with $S a c I$ and $X b a I$ and were inserted back into the plasmid pICPPV-NK-lGFP. Resulting vectors pICPPV-NK-1GFP-CP ${ }^{\mathrm{T} 254 \mathrm{~A} / \mathrm{T} 254 \mathrm{D} / \mathrm{T} 254 \mathrm{~T}^{*} / \mathrm{T} 254 \mathrm{~K} / \mathrm{T} 313 \mathrm{~A} / \mathrm{T} 313 \mathrm{D} / \mathrm{T} 313 \mathrm{~N}}$ $\left(\mathrm{CP}^{\mathrm{T} 254 \mathrm{~A} / \mathrm{T} 254 \mathrm{D} / \mathrm{T} 254 \mathrm{~T} * / \mathrm{T} 254 \mathrm{~K} / \mathrm{T} 313 \mathrm{~A} / \mathrm{T} 313 \mathrm{D} / \mathrm{T} 313 \mathrm{~N}}\right)$ were used to mechanically inoculate $N$. benthamiana plants (Supplementary Fig. S2).

Next, mutant cDNA clones $\mathrm{CP}^{\mathrm{T} 254 \mathrm{D}}$ and $\mathrm{CP}^{\mathrm{T} 313 \mathrm{D}}$, containing changes T254D and T313D, were digested with MauBI and SacI in order to replace the corresponding fragment into the binary vector pLX-PPV (Pasin et al. 2017). Resulting constructs pLX-PPV-CP ${ }^{\mathrm{T} 254 \mathrm{D}}\left(\mathrm{aCP}^{\mathrm{T} 254 \mathrm{D}}\right)$ and $\mathrm{pLX}-\mathrm{PPV}-$ $\mathrm{CP}^{\mathrm{T} 313 \mathrm{D}}\left(\mathrm{aCP}^{\mathrm{T} 313 \mathrm{D}}\right)$ were employed in agroinoculation assays (Supplementary Fig. S2). Other constructs used in these experiments included clones that express the silencing suppressor of CVYV P1b, pMDC-P1b (Rodamilans et al. 2013), and a plasmid expressing the RFP, pGWB-RFP (Tanaka et al. 2011), as well as the PPV full-length cDNA clones pBIN-PPV-CI ${ }^{\mathrm{DD} 3,4 \mathrm{AA}}$ $\left(\mathrm{aCI}^{\mathrm{DD} 3,4 \mathrm{AA}}\right)$ and pBIN-PPV-CI ${ }^{\mathrm{KS} 91,92 \mathrm{AA}}\left(\mathrm{CI}^{\mathrm{KS} 91,92 \mathrm{AA}}\right)$ (A. Gallo and J. A. García unpublished results), which express CI mutants deficient in viral movement and replication, respectively (Gómez de Cedrón et al. 2006).

\section{Viral inoculation.}

Mechanical inoculations were carried out by hand rubbing, using Carborundum as an abrasive agent, as previously described (Martínez-Turiño et al. 2018). Inoculums consisted of $10 \mu \mathrm{l}$ of cDNA clones $(1 \mu \mathrm{g} / \mu \mathrm{l})$ per leaf or crude extracts of
PPV-infected $N$. benthamiana leaves ( $1 \mathrm{~g}$ of leaf tissue in $2 \mathrm{ml}$ of $5 \mathrm{mM}$ sodium phosphate, $\mathrm{pH}$ 7.2).

Agroinoculation or transient expressions assays were done by infiltration with Agrobacterium tumefaciens GV3101 (pMP90), as previously described (Gallo et al. 2018). For complete leaf infiltration, agroinoculation mixtures included pLX-PPV- or pBIN-PPV-derived clones (optical density at $\left.600 \mathrm{~nm}\left[\mathrm{OD}_{600}\right]=0.7\right)$, along with pMDC-P1b $\left(\mathrm{OD}_{600}=0.3\right)$. In patch-restricted agroinfiltrations, pLX-PPV- or pBINderived clones $\left(\mathrm{OD}_{600}=0.45\right)$ were delivered together with pMDC-P1b $\left(\mathrm{OD}_{600}=0.3\right)$ and pGWB-RFP $\left(\mathrm{OD}_{600}=0.25\right)$.

Viral inoculations (by hand rubbing or agroinoculation) were done over three leaves of young $N$. benthamiana plants (four- to six-leaf stage). Plants were cultured at 19 to $24^{\circ} \mathrm{C}$ in a glasshouse with a 16-h light photoperiod with supplementary illumination.

\section{Assessment of viral infection and fluorescence imaging.}

Virus infection was assessed by visual inspection of symptoms and monitoring the GFP expressed from PPV clones under a long-wavelength UV lamp or a with a Leica MZ FLIII stereomicroscope (Leica Microsystems) with excitation and barrier filters of $480 / 40$ and $510 \mathrm{~nm}$, respectively. RFP fluorescence was visualized with the same stereomicroscope, with excitation and barrier filters of $546 / 10$ and $570 \mathrm{~nm}$, respectively. Fluorescence images were acquired as described by Martínez-Turiño et al. (2018).

PPV accumulation was determined on the basis of $\mathrm{CP}$ amount, by Western blot analysis as described (Pérez et al. 2006). Total protein content of the samples was checked by Ponceau red staining, except in the case of samples from centrifugation in sucrose gradient, for which total protein levels were undetectable by this method and were therefore not taken into account.

\section{Nucleic acid sequence analysis.}

Characterization of the viral progeny genome was carried out by RT-PCR or IC-RT-PCR as described (Martínez-Turiño et al. 2018). All amplified fragments, covering the whole CP, were obtained using oligos SM30-F-ext and 55 (Supplementary Table S2) and were subjected to Sanger sequencing by Macrogen Europe (Amsterdam).

Verification of changes introduced by direct mutagenesis in pICPPV-NK-1GFP- or pLX-PPV-derived clones, was done using primer pairs 2429 and SM13-1GFP or 2429 and SM13-GFP, respectively (Supplementary Table S2).

\section{Analysis of CP stability.}

Preparation of cell-free extracts and endogenous in-vitro degradation assays were carried out as previously described (Valli et al. 2014). Native extracts from agroinfiltrated leaves (EAL) or cell-free extracts from systemically infected leaves (ESIL), not incubated $(t=0)$ or incubated for $1 \mathrm{~h}$ at $25^{\circ} \mathrm{C}(t=$ $60)$, were subjected to fractionation by centrifugation (Beckman Coulter Optima L-100 XP) in a continuous sucrose gradient (10 to $40 \%$ ), as previously described (Gallo et al. 2018). A total of 11 fractions of around $500 \mu \mathrm{l}$ (for EAL) or 18 fractions of around $250 \mu \mathrm{l}$ (for ESIL) were collected, using a capillary tube placed at the bottom of the tube and dropping samples by gravity. Aliquots were analyzed by Western blot to detect PPV CP.

Structure of virions was studied by ISEM as previously described (Valli et al. 2014). Grids were observed using a JEM 1011 electron microscope (Jeol) and images were taken under an ES1000W Erlangshen charge-coupled-device camera (Gatan). A minimum of three fields per grid and two grids per sample was examined, in order to account for at least 20 viral particles in each, usually assessing between 35 and 50 particles per grid. 


\section{Strand-specific RT-qPCR analysis.}

Viral RNA replication was analyzed by quantification of virus-derived negative RNA using strand-specific RT-qPCR, as previously described (Pasin et al. 2014).

Total RNA was obtained from $N$. benthamiana agroinfiltrated leaves with a FavorPrep plant total RNA purification minikit (Favorgen Biotech). cDNAs were synthesized from genomic RNA by using the primer Q29-F, and negative-strand quantification was done with the primer pair Q30-F and Q31-R (Supplementary Table S2). Reaction mixtures were prepared with HOT FIRE Pol Eva Green qPCR Mix Plus (Solis BioDyne), added to 96-well optical plates and processed in a 7500 RealTime PCR system (Applied Biosystems).

\section{Proteomic approaches.}

PPV virions were purified from manually inoculated $N$. benthamiana plants infected with WT PPV or the 4SA mutant as previously described (Laín et al. 1988), with slight modifications (Chen et al. 2005).

\section{D-PAGE analysis.}

Approximately $2 \mu \mathrm{g}$ of PPV virions were subjected to $2 \mathrm{D}$ electrophoresis. For first dimension, samples cleaned using the Clean-up kit (GE Healthcare, Life Science) and suspended in UTC buffer (7 M urea, $2 \mathrm{M}$ thiourea, 4\% CHAPS) were applied in a rehydrated IPG Ready Strip, $\mathrm{pH} 4$ to 7, $11 \mathrm{~cm}$ (Bio-Rad). Electrofocusing was carried out as follows: $120 \mathrm{~V}(1 \mathrm{~h}), 250 \mathrm{~V}$ $(1 \mathrm{~h}), 500 \mathrm{~V}(1 \mathrm{~h}), 1,000 \mathrm{~V}(0.5 \mathrm{~h})$, gradual ramping to $8,000 \mathrm{~V}$ $(0.5 \mathrm{~h})$ and $8,000 \mathrm{~V}$ (until 30,000 volt hours). For second dimension, strips containing samples and a molecular weight marker (Novex) were subjected to electrophoresis in sodium dodecyl sulfate-PAGE $12 \%$ in a Midi format system (Bio-Rad). Gels were stained with Coomassie blue G250 (Generon).

\section{Electrospray ionization MS/MS.}

PPV virions were precipitated with methanol-chloroform, were reconstituted in a buffer containing $8 \mathrm{M}$ urea and $25 \mathrm{mM}$ ammonium bicarbonate, and, after reduction with $10 \mathrm{mM}$ dithiothreitol and alkylation with $50 \mathrm{mM}$ iodoacetamide, were proteolysed with Lys-C (6 h) and trypsin (15 h) (enzyme/substrate ratio 1:50). For phosphopeptide enrichment, two in housepacked microcolumns, IMAC and Oligo R3 reverse-phase, were concatenated for selective purification and sample clean-up before liquid chromatography coupled to MS/MS (LC-MS/MS) analysis (Navajas et al. 2011). Phosphopeptide-enriched fractions were subjected to a nano LC-MS/MS Triple TOF system in a data-dependent acquisition mode, in which up to 15 precursor ions per MS cycle were monitored and selected for fragmentation, as described by Martínez-Turiño et al. (2018).

MS and MS/MS data were converted to MGF files, which were searched against a PPV protein database containing 13 protein sequences using the Mascot Server v.2.6.1 (Matrix Science) and the Peaks Search engine (BSI Peaks Studio 7.0). Search parameters were set as follows: no enzyme restriction, fixed modifications, carbamidomethylation of cysteine; variable modifications, oxidation of methionine, phosphorylation and glycosylation (HexNAc) of serine and threonine, and phosphorylation of tyrosine.

MS proteomics data have been deposited to the ProteomeXchange and Mass Spectrometry Interactive Virtual Environment (MassIVE) data repositories with the dataset identifiers PXD017237 and MSV000084823, respectively.

\section{PPV CP modeling.}

The monomer of PPV CP was modeled with I-TASSER (Yang et al. 2015), based on the WMV CP atomic structure (PDB code 5ODV) (Zamora et al. 2017). Following the personal advice of the authors, the numbering of WMV CP residues was corrected by a -2 amino acid shift. The PyMOL Molecular Graphics System, version 1.7.4 (Schrödinger) was used for visualization of 3D protein structures.

The oligomeric complex for PPV virions was obtained by rigid-body fitting of PPV monomer with each of the subunits of the WMV. Protein sequences of WMV CP and PPV CP were retrieved from the RefSeq database at the National Center for Biotechnology Information (O'Leary et al. 2016). Sequence alignment was carried out with the Clustal Omega web server (Sievers et al. 2011) using default parameters. Residues participating in interchain interfaces of the WMV CP oligomer were obtained from PDBSum (Laskowski et al. 2018).

\section{AUTHOR-RECOMMENDED INTERNET RESOURCES}

Clustal Omega multiple sequence alignment page: https://www.ebi.ac.uk/Tools/msa/clustalo

PDBSum: www.ebi.ac.uk/pdbsum

\section{ACKNOWLEDGMENTS}

We thank B. García for technical assistance. We also thank the Electron Microscopy and the Advance Light Microscopy facilities at the National Center for Biotechnology Spanish National Research Council.

\section{LITERATURE CITED}

Atabekov, J. G., Rodionova, N. P., Karpova, O. V., Kozlovsky, S. V., Novikov, V. K., and Arkhipenko, M. V. 2001. Translational activation of encapsidated potato virus X RNA by coat protein phosphorylation. Virology 286:466-474.

Champagne, J., Laliberté-Gagné, M. E., and Leclerc, D. 2007. Phosphorylation of the termini of Cauliflower mosaic virus precapsid protein is important for productive infection. Mol. Plant-Microbe Interact 20: 648-658.

Chen, D., Juárez, S., Hartweck, L., Alamillo, J. M., Simón-Mateo, C., Pérez, J. J., Fernández-Fernández, M. R., Olszewski, N. E., and García, J. A. 2005. Identification of secret agent as the $O$-GlcNAc transferase that participates in plum pox virus infection. J. Virol. 79:9381-9387.

Cheng, X., Xiong, R., Li, Y., Li, F., Zhou, X., and Wang, A. 2017 Sumoylation of Turnip mosaic virus RNA polymerase promotes viral infection by counteracting the host NPR1-mediated immune response. Plant Cell 29:508-525.

Chung, B. Y. W., Miller, W. A., Atkins, J. F., and Firth, A. E. 2008. An overlapping essential gene in the Potyviridae. Proc. Natl. Acad. Sci. U.S.A. 105:5897-5902.

Citovsky, V., McLean, B. G., Zupan, J. R., and Zambryski, P. 1993. Phosphorylation of tobacco mosaic virus cell-to-cell movement protein by a developmentally regulated plant cell wall-associated protein kinase. Genes Dev. 7:904-910.

Cuesta, R., Yuste-Calvo, C., Gil-Cartón, D., Sánchez, F., Ponz, F., and Valle, M. 2019. Structure of Turnip mosaic virus and its viral-like particles. Sci. Rep. 9:15396.

Dolja, V. V., Haldeman, R., Robertson, N. L., Dougherty, W. G., and Carrington, J. C. 1994. Distinct functions of capsid protein in assembly and movement of tobacco etch potyvirus in plants. EMBO J. 13: 1482-1491.

Fernández-Fernández, M. R., Camafeita, E., Bonay, P., Méndez, E., Albar, J. P., and García, J. A. 2002. The capsid protein of a plant single-stranded RNA virus is modified by $O$-linked $N$-acetylglucosamine. J. Biol. Chem. 277:135-140.

Gallo, A., Valli, A., Calvo, M., and García, J. A. 2018. A functional link between RNA replication and virion assembly in the potyvirus Plum pox virus. J. Virol. 92:e02179-17.

Gelens, L., and Saurin, A. T. 2018. Exploring the function of dynamic phosphorylation-dephosphorylation cycles. Dev. Cell 44:659-663.

Gómez de Cedrón, M., Osaba, L., López, L., and García, J. A. 2006. Genetic analysis of the function of the plum pox virus CI RNA helicase in virus movement. Virus Res. 116:136-145.

Hafrén, A., Hofius, D., Rönnholm, G., Sonnewald, U., and Mäkinen, K. 2010. HSP70 and its cochaperone CPIP promote potyvirus infection in Nicotiana benthamiana by regulating viral coat protein functions. Plant Cell 22:523-535. 
Hipp, K., Zikeli, K., Kepp, G., Schmid, L., Shoeman, R. L., Jurkowski, T. P., Kleinow, T., and Jeske, H. 2019. Different forms of African cassava mosaic virus capsid protein within plants and virions. Virology 529: 81-90.

Ho, S. N., Hunt, H. D., Horton, R. M., Pullen, J. K., and Pease, L. R. 1989. Site-directed mutagenesis by overlap extension using the polymerase chain reaction. Gene 77:51-59.

Hoover, H. S., and Kao, C. C. 2016. Phosphorylation of the viral coat protein regulates RNA virus infection. Virus Adapt. Treat. 8:13-20.

Hoover, H. S., Wang, J. C., Middleton, S., Ni, P., Zlotnick, A., Vaughan, R. C., and Kao, C. C. 2016. Phosphorylation of the brome mosaic virus capsid regulates the timing of viral infection. J. Virol. 90:7748-7760.

Hu, Y., Li, Z., Yuan, C., Jin, X., Yan, L., Zhao, X., Zhang, Y., Jackson, A. O., Wang, X., Han, C., Yu, J., and Li, D. 2015. Phosphorylation of TGB1 by protein kinase CK2 promotes barley stripe mosaic virus movement in monocots and dicots. J. Exp. Bot. 66:4733-4747.

Hung, C. J., Huang, Y. W., Liou, M. R., Lee, Y. C., Lin, N. S., Meng, M., Tsai, C. H., Hu, C. C., and Hsu, Y. H. 2014. Phosphorylation of coat protein by protein kinase $\mathrm{CK} 2$ regulates cell-to-cell movement of Bamboo mosaic virus through modulating RNA binding. Mol. PlantMicrobe Interact 27:1211-1225.

Ivanov, K. I., Eskelin, K., Lõhmus, A., and Mäkinen, K. 2014. Molecular and cellular mechanisms underlying potyvirus infection. J. Gen. Virol. 95:1415-1429.

Ivanov, K. I., and Mäkinen, K. 2012. Coat proteins, host factors and plant viral replication. Curr. Opin. Virol. 2:712-718.

Ivanov, K. I., Puustinen, P., Gabrenaite, R., Vihinen, H., Rönnstrand, L., Valmu, L., Kalkkinen, N., and Mäkinen, K. 2003. Phosphorylation of the potyvirus capsid protein by protein kinase CK2 and its relevance for virus infection. Plant Cell 15:2124-2139.

Ivanov, K. I., Puustinen, P., Merits, A., Saarma, M., and Mäkinen, K. 2001. Phosphorylation down-regulates the RNA binding function of the coat protein of potato virus A. J. Biol. Chem. 276:13530-13540.

Jakubiec, A., and Jupin, I. 2007. Regulation of positive-strand RNA virus replication: The emerging role of phosphorylation. Virus Res. 129: 73-79.

Jakubiec, A., Tournier, V., Drugeon, G., Pflieger, S., Camborde, L., Vinh, J., Héricourt, F., Redeker, V., and Jupin, I. 2006. Phosphorylation of viral RNA-dependent RNA polymerase and its role in replication of a plusstrand RNA virus. J. Biol. Chem. 281:21236-21249.

Keating, J. A., and Striker, R. 2012. Phosphorylation events during viral infections provide potential therapeutic targets. Rev. Med. Virol. 22: 166-181.

Keck, F., Ataey, P., Amaya, M., Bailey, C., and Narayanan, A. 2015. Phosphorylation of single stranded RNA virus proteins and potential for novel therapeutic strategies. Viruses 7:5257-5273.

Kežar, A., Kavčič, L., Polák, M., Nováček, J., Gutiérrez-Aguirre, I., Žnidarič, M. T., Coll, A., Stare, K., Gruden, K., Ravnikar, M., Pahovnik, D., Žagar, E., Merzel, F., Anderluh, G., and Podobnik, M. 2019. Structural basis for the multitasking nature of the potato virus Y coat protein. Sci. Adv. 5:eaaw3808.

Kim, B. S., Halk, E. L., Merlo, D. J., Nelson, S. E., and Loesch-Fries, L. S. 2014. Phosphorylation of alfalfa mosaic virus movement protein in vivo. Arch. Virol. 159:1787-1791.

Kim, S. H., Palukaitis, P., and Park, Y. I. 2002. Phosphorylation of cucumber mosaic virus RNA polymerase 2a protein inhibits formation of replicase complex. EMBO J. 21:2292-2300.

Kim, Y. C., Udeshi, N. D., Balsbaugh, J. L., Shabanowitz, J., Hunt, D. F., and Olszewski, N. E. 2011. O-GlcNAcylation of the Plum pox virus capsid protein catalyzed by SECRET AGENT: Characterization of O-GlcNAc sites by electron transfer dissociation mass spectrometry. Amino Acids 40:869-876.

Kobir, A., Shi, L., Boskovic, A., Grangeasse, C., Franjevic, D., and Mijakovic, I. 2011. Protein phosphorylation in bacterial signal transduction. Biochim. Biophys. Acta 1810:989-994.

Laín, S., Riechmann, J. L., Méndez, E., and García, J. A. 1988. Nucleotide sequence of the $3^{\prime}$ terminal region of plum pox potyvirus RNA. Virus Res. 10:325-341.

Laskowski, R. A., Jabłońska, J., Pravda, L., Vařeková, R. S., and Thornton, J. M. 2018. PDBsum: Structural summaries of PDB entries. Protein Sci. 27:129-134.

Law, L. M. J., Everitt, J. C., Beatch, M. D., Holmes, C. F. B., and Hobman, T. C. 2003. Phosphorylation of rubella virus capsid regulates its RNA binding activity and virus replication. J. Virol. 77:1764-1771.

Li, Y., Sun, L., Zheng, W., Madina Mahesutihan, Li, J., Bi, Y., Wang, H., Liu, W., and Luo, T. R. 2018. Phosphorylation and dephosphorylation of threonine 188 in nucleoprotein is crucial for the replication of influenza A virus. Virology 520:30-38.
Lõhmus, A., Hafrén, A., and Mäkinen, K. 2017. Coat protein regulation by CK2, CPIP, HSP70, and CHIP is required for potato virus A replication and coat protein accumulation. J. Virol. 91:e01316-16.

Martínez-Turiño, S., Pérez, J. J., Hervás, M., Navajas, R., Ciordia, S., Udeshi, N. D., Shabanowitz, J., Hunt, D. F., and García, J. A. 2018 Phosphorylation coexists with $O$-GlcNAcylation in a plant virus protein and influences viral infection. Mol. Plant Pathol. 19:1427-1443.

Módena, N. A., Zelada, A. M., Conte, F., and Mentaberry, A. 2008. Phosphorylation of the TGBp1 movement protein of Potato virus $X$ by a Nicotiana tabacum CK2-like activity. Virus Res. 137:16-23.

Mondal, A., Potts, G. K., Dawson, A. R., Coon, J. J., and Mehle, A. 2015. Phosphorylation at the homotypic interface regulates nucleoprotein oligomerization and assembly of the influenza virus replication machinery. PLoS Pathog. 11:e1004826.

Mundy, J., and Schneitz, K. 2002. Protein phosphorylation in and around signal transduction. Trends Plant Sci. 7:54-55.

Navajas, R., Paradela, A., and Albar, J. P. 2011. Immobilized metal affinity chromatography/reversed-phase enrichment of phosphopeptides and analysis by CID/ETD tandem mass spectrometry. Methods Mol. Biol. 681:337-348

Nemes, K., Gellért, Á., Almási, A., Vági, P., Sáray, R., Kádár, K., and Salánki, K. 2017. Phosphorylation regulates the subcellular localization of Cucumber Mosaic Virus 2b protein. Sci. Rep. 7:13444

Nemes, K., Gellért, Á., Bóka, K., Vági, P., and Salánki, K. 2019. Symptom recovery is affected by Cucumber mosaic virus coat protein phosphorylation. Virology 536:68-77.

O’Leary, N. A., Wright, M. W., Brister, J. R., Ciufo, S., Haddad, D., McVeigh, R., Rajput, B., Robbertse, B., Smith-White, B., Ako-Adjei, D., Astashyn, A., Badretdin, A., Bao, Y., Blinkova, O., Brover, V. Chetvernin, V., Choi, J., Cox, E., Ermolaeva, O., Farrell, C. M., Goldfarb, T., Gupta, T., Haft, D., Hatcher, E., Hlavina, W., Joardar, V. S., Kodali, V. K., Li, W., Maglott, D., Masterson, P., McGarvey, K. M., Murphy, M. R., O’Neill, K., Pujar, S., Rangwala, S. H., Rausch, D., Riddick, L. D., Schoch, C., Shkeda, A., Storz, S. S., Sun, H., ThibaudNissen, F., Tolstoy, I., Tully, R. E., Vatsan, A. R., Wallin, C., Webb, D., Wu, W., Landrum, M. J., Kimchi, A., Tatusova, T., DiCuccio, M., Kitts, P., Murphy, T. D., and Pruitt, K. D. 2016. Reference sequence (RefSeq) database at NCBI: Current status, taxonomic expansion, and functional annotation. Nucleic Acids Res. 44 (D1):D733-D745.

Olspert, A., Chung, B. Y., Atkins, J. F., Carr, J. P., and Firth, A. E. 2015. Transcriptional slippage in the positive-sense RNA virus family Potyviridae. EMBO Rep. 16:995-1004.

Pasin, F., Bedoya, L. C., Bernabé-Orts, J. M., Gallo, A., Simón-Mateo, C., Orzáez, D., and García, J. A. 2017. Multiple T-DNA delivery to plants using novel mini binary vectors with compatible replication origins. ACS Synth. Biol. 6:1962-1968.

Pasin, F., Kulasekaran, S., Natale, P., Simón-Mateo, C., and García, J. A 2014. Rapid fluorescent reporter quantification by leaf disc analysis and its application in plant-virus studies. Plant Methods 10:22.

Pawson, T., and Scott, J. D. 2005. Protein phosphorylation in signaling-50 years and counting. Trends Biochem. Sci. 30:286-290.

Pérez, J. J., Juárez, S., Chen, D., Scott, C. L., Hartweck, L. M., Olszewski, N. E., and Garćia, J. A. 2006. Mapping of two O-GlcNAc modification sites in the capsid protein of the potyvirus Plum pox virus. FEBS Lett. 580:5822-5828.

Pérez, J. J., Udeshi, N. D., Shabanowitz, J., Ciordia, S., Juárez, S., Scott, C. L., Olszewski, N. E., Hunt, D. F., and García, J. A. 2013. O-GlcNAc modification of the coat protein of the potyvirus Plum pox virus enhances viral infection. Virology 442:122-131.

Ranadheera, C., Proulx, R., Chaiyakul, M., Jones, S., Grolla, A., Leung, A., Rutherford, J., Kobasa, D., Carpenter, M., and Czub, M. 2018. The interaction between the Nipah virus nucleocapsid protein and phosphoprotein regulates virus replication. Sci. Rep. 8:15994.

Revers, F., and García, J. A. 2015. Molecular biology of potyviruses. Adv. Virus Res. 92:101-199.

Rodamilans, B., Valli, A., and García, J. A. 2013. Mechanistic divergence between P1 proteases of the family Potyviridae. J. Gen. Virol. 94: 1407-1414.

Rodamilans, B., Valli, A., Mingot, A., San León, D., Baulcombe, D., López-Moya, J. J., and García, J. A. 2015. RNA polymerase slippage as a mechanism for the production of frameshift gene products in plant viruses of the Potyviridae family. J. Virol. 89:6965-6967.

Samuilova, O., Santala, J., and Valkonen, J. P. 2013. Tyrosine phosphorylation of the triple gene block protein 3 regulates cell-to-cell movemen and protein interactions of Potato mop-top virus. J. Virol. 87:4313-4321.

Shapka, N., Stork, J., and Nagy, P. D. 2005. Phosphorylation of the p33 replication protein of Cucumber necrosis tombusvirus adjacent to the RNA binding site affects viral RNA replication. Virology 343:65-78. 
Shukla, D. D., Strike, P. M., Tracy, S. L., Gough, K. H., and Ward, C. W. 1988. The $\mathrm{N}$ and $\mathrm{C}$ termini of the coat proteins of potyviruses are surface-located and the $\mathrm{N}$-terminus contains the major virus-specific epitopes. J. Gen. Virol. 69:1497-1508.

Sievers, F., Wilm, A., Dineen, D., Gibson, T. J., Karplus, K., Li, W., Lopez, R., McWilliam, H., Remmert, M., Söding, J., Thompson, J. D., and Higgins, D. G. 2011. Fast, scalable generation of high-quality protein multiple sequence alignments using Clustal Omega. Mol. Syst. Biol. 7: 539-539.

Sokolova, M., Prüfer, D., Tacke, E., and Rohde, W. 1997. The potato leafroll virus $17 \mathrm{~K}$ movement protein is phosphorylated by a membraneassociated protein kinase from potato with biochemical features of protein kinase C. FEBS Lett. 400:201-205.

Šubr, Z., Ryšlavá, H., and Kollerová, E. 2007. Electrophoretic mobility of the capsid protein of the Plum pox virus strain PPV-Rec indicates its partial phosphorylation. Acta Virol. 51:135-138.

Šubr, Z. W., Kamencayová, M., Nováková, S., Nagyová, A., Nosek, J., and Glasa, M. 2010. A single amino acid mutation alters the capsid protein electrophoretic double-band phenotype of the Plum pox virus strain PPVRec. Arch. Virol. 155:1151-1155.

Tanaka, Y., Nakamura, S., Kawamukai, M., Koizumi, N., and Nakagawa, T. 2011. Development of a series of gateway binary vectors possessing a tunicamycin resistance gene as a marker for the transformation of Arabidopsis thaliana. Biosci. Biotechnol. Biochem. 75: 804-807.

Valli, A., Gallo, A., Calvo, M., de Jesús Pérez, J., and García, J. A. 2014. A novel role of the potyviral helper component proteinase contributes to enhance the yield of viral particles. J. Virol. 88:9808-9818.

Valli, A., García, J. A., and López-Moya, J. J. 2020. Potyviruses (Potyviridae). In: Encyclopedia of Virology, Fourth ed. N. S. Iacobellis, A. Collmer, S. W. Hutcheson, J. W. Mansfield, C. E. Morris, J. Murillo,
N. W. Schaad, D. E. Stead, G. Surico, and M. Ullrich, eds. Kluwer Academic Elseviers, Dordrecht, The Netherlands.

van der Laarse, S. A. M., Leney, A. C., and Heck, A. J. R. 2018. Crosstalk between phosphorylation and O-GlcNAcylation: Friend or foe. FEBS J. 285:3152-3167.

Varrelmann, M., and Maiss, E. 2000. Mutations in the coat protein gene of plum pox virus suppress particle assembly, heterologous encapsidation and complementation in transgenic plants of Nicotiana benthamiana. J. Gen. Virol. 81:567-576.

$\mathrm{Xu}$, J., and Zhang, S. 2015. Mitogen-activated protein kinase cascades in signaling plant growth and development. Trends Plant Sci. 20:56-64.

Xu, S. L., Chalkley, R. J., Maynard, J. C., Wang, W., Ni, W., Jiang, X., Shin, K., Cheng, L., Savage, D., Hühmer, A. F., Burlingame, A. L., and Wang, Z. Y. 2017. Proteomic analysis reveals O-GlcNAc modification on proteins with key regulatory functions in Arabidopsis. Proc. Natl. Acad. Sci. U.S.A. 114:E1536-E1543.

Yang, J., Yan, R., Roy, A., Xu, D., Poisson, J., and Zhang, Y. 2015. The I-TASSER suite: Protein structure and function prediction. Nat. Methods 12:7-8.

Zamora, M., Méndez-López, E., Agirrezabala, X., Cuesta, R., Lavín, J. L., Sánchez-Pina, M. A., Aranda, M. A., and Valle, M. 2017. Potyvirus virion structure shows conserved protein fold and RNA binding site in ssRNA viruses. Sci. Adv. 3:eaao2182.

Zhang, X., Dong, K., Xu, K., Zhang, K., Jin, X., Yang, M., Zhang, Y., Wang, X., Han, C., Yu, J., and Li, D. 2018. Barley stripe mosaic virus infection requires PKA-mediated phosphorylation of $\gamma \mathrm{b}$ for suppression of both RNA silencing and the host cell death response. New Phytol. 218:1570-1585.

Zhao, X., Wang, X., Dong, K., Zhang, Y., Hu, Y., Zhang, X., Chen, Y., Wang, X., Han, C., Yu, J., and Li, D. 2015. Phosphorylation of Beet black scorch virus coat protein by PKA is required for assembly and stability of virus particles. Sci. Rep. 5:11585. 